\title{
KULEUVEN
}

\section{Patent notice (failure) in the era of Patent Monetization}




\title{
Patent Notice (Failure) in the Era of Patent Monetization*
}

\author{
Arina Gorbatyuk ${ }^{+}$and Adrián Kovács ${ }^{++}$ \\ ${ }^{+}$Centre for IT \& IP Law (CiTiP), KU Leuven, Leuven, Belgium, arina.gorbatyuk@kuleuven.be. \\ ${ }^{++}$Department of Management, Strategy \& Innovation, KU Leuven, Leuven, Belgium, adrian.kovacs@kuleuven.be.
}

\begin{abstract}
The most commonly provided economic rationale for the patent system is that it incentivizes inventive effort that may not be carried out in its absence. In addition to this utilitarian rationale, economic and legal scholars often refer to a second rationale that underlies the patent system - the dissemination of technological information to the public. This notice function is thought of as an important mechanism to enable a more efficient investment in innovation by stimulating further (cumulative) innovation, reducing wasteful duplicate innovative effort and limiting unnecessary litigation. Consequently, courts have placed a great deal of emphasis on the notice function and have described it as the 'quid pro quo' of granting patent owners the right to exclude. Whereas the notice function is traditionally confined to the adequate disclosure of inventions, we propose that in light of the recent trend towards rapidly growing markets for patent monetization it should also encompass the adequate disclosure of the holders of rights to a patent. Specifically, in this paper we argue that in addition to knowing in detail the boundaries that define a claimed invention, knowing the identity of the parties that hold rights to this invention is a fundamental prerequisite for any patent transaction to occur. Based on a comparative analysis of the provisions of six of the most proficient patent offices worldwide, we illustrate that although current provisions warrant an adequate disclosure of the identity of the initial patent applicant(s), they provide the public with only limited opportunities to identify and track subsequent changes of ownership. Although most patent authorities require parties to file notice when the rights to a patent are assigned, provisions for strictly enforcing this requirement are absent. This allows for a lack of transparency concerning patent ownership, which may hamper rather than facilitate technology transactions.
\end{abstract}

Keywords; Patent Disclosure, Patent Assignments, Markets for Technology, Patent Monetization. JEL Classification; K11; O32; Q55.

\footnotetext{
${ }^{*}$ Working paper draft, version June 2019. Please do not cite or redistribute without permission of the authors. All errors are our own.
} 


\section{Introduction}

Legal and economic commentators have described a trend towards the monetization of patents that is manifested in both the increasing number of patent transactions and the monetary gains generated by them ${ }^{1}$ Whilst the attribution of this trend varies from the institutional commodification and assetization of patents to changes in contextual factors that have forced organizations to open up their innovation processes, there is a consensus that patent monetization is on the rise from the mid-1990s onwards. ${ }^{2}$ This trend coincides with the rise of markets for technology wherein exchanges comprise intermediate technological inputs that are largely disembodied from goods and services $3^{3}$ Although technology markets have the potential to be engines of economic growth, in the sense that they enable a division of labor between the entities that invent and the entities that manufacture most efficiently, it is widely recognized that they function inefficiently due to information asymmetries between buyers and sellers of technology that arise due to the public good nature of inventions.4 Patents can, at least in part, provide a remedy to this matter by simultaneously enabling purposive knowledge flows and limiting unintended knowledge spillovers. Specifically, patents may facilitate technology transactions by: (i) protecting buyers and sellers of technology against the expropriation of inventions (the appropriation function) and (ii) by aiding contract negotiations between buyers and sellers via the disclosure of technical details concerning the invention (the notice function). For patents to facilitate technology transactions it is of paramount importance that patent offices provide

\footnotetext{
${ }^{1}$ See e.g. David Teece and Peter Grindley, Managing Intellectual Capital: Licensing and Cross-Licensing in Semiconductors and Electronics, CAL. MAN. REV. 39, 8-41 (1997) (reporting a significant increase in the licensing revenues of Texas Instruments from US $\$ 50$ million in 1986 to more tan US\$500 million in the mid-1990s); Kevin Rivette and David Kline, Rembrandts in the Attic: Unlocking the Hidden Value of Patents (2000) (reporting that IBM increased its licensing royalties from US\$100 million in 1990 to almost US\$ 1 billion in 1999).

2 See Rochelle Dreyfuss and Susy Frankel, From Incentive to Commodity to Asset: How International Law is Reconceptualizing Intellectual Property, MICH. J. INT. LAW 36, 557, 566 (2015) (arguing that "multilateral soft an hard laws, as well as bilateral, plurilateral, and regional agreements" have reconceptualized IP as an asset and have "progressively detached it from its grounding in incentive-based principles"); Henry Chesbrough Marcel Bogers, Explicating Open Innovation: Clarifying an Emerging Paradigm for Understanding Innovation, in Henry Chesbrough et. al., New Frontiers in Open Innovation 1, 27 (2014) (observing that companies cannot afford to solely rely on their own R\&D in an era in which the sources of knowledge for innovation are widely distributed in the economy).

${ }^{3}$ See Ashish Arora et. al., Markets for Technology: The Economics of Innovation and Corporate Strategy ch.1. 1, 2 (2001) ("This vision of knowledge creation integrated with knowledge use has become inadequate for understanding economic growth in the twenty-first century. Over the past ten to fifteen years, there has been a rapid growth in a variety of arrangements for the exchange of technologies or technological services, ranging from R\&D joint ventures and partnerships to licensing and cross-licensing agreements, to contracted R\&D. Although we lack comprehensive empirical measures of the increase in such arrangements over time, all the available evidence suggests that the trade in technologies is more common than it was in the past.").

${ }^{4}$ See Ashish Arora and Alfonso Gambardella, Ideas for Rent: An Overview of Markets for Technology, IND. CORP. CHANGE., 19, 775, 787 (2010) (denoting uncertainty concerning (i) property rights, (ii) the value of technology and (iii) transaction processes as persistent barriers to the efficient functioning of technology markets)
} 
complete and accurate information to the public regarding the holders of patent rights 5 In other words, patent ownership information is a critical constituent of the notice function of the patent system.

In this paper, we argue that current regulations do not allow to establish with certainty who owns a particular patent. Specifically, we focus on patent ownership changes and highlight that, whilst patent offices impose strict legal requirements concerning the adequate disclosure of the identity of the initial applicant(s) of a patent, their requirements are considerably less strict with respect to the disclosure of ownership once patent rights have been assigned to other parties. In other words, the likelihood of identifying the actual owner(s) of a patent is significantly reduced following changes in the ownership of the patent. Hence, somewhat paradoxically, whilst a greater transparency of patent ownership facilitates technology transactions, such transactions might in fact result in a decrease of the transparency of ownership in return. We highlight that this is the result of insufficient requirements for the registration of assignments as currently imposed by patent offices and the enforcement thereof and illustrate the universal nature of this issue based on a comparative analysis of rules on the establishment of patent ownership throughout the patent lifecycle of one regional patent office - the European Patent Office (hereafter EPO) - and five national patent offices - the United States Patent and Trademark Office (hereafter USPTO), the Japan Patent Office (hereafter JPO), the United Kingdom Intellectual Property Office (hereafter UK IPO), the French Institut National de la Propriété Industrielle (hereafter INPI) and the German Patent and Trademark Office (hereafter DPMA).

Our analysis reveals that the patent application stage, at which the initial title in a patent is established, is the only stage during the lifetime of a patent at which the adequate disclosure of the identities of the holders of rights to a patent is strictly enforced. Although all patent offices under study require parties to file notice when a patent is assigned, no provisions exist for strictly enforcing the failure to meet this requirement. Despite the clear detrimental implications of a failure to disclose information concerning the identities of patent owners for the functioning of technology markets, we could only identify one initiative that aims to remedy the flaws of current patent provisions - the USPTO's Notice on "Changes to Require Identification of Attributable Owner". We rely on a discussion of the relevant elements of this Notice as a foundation for proposing a number of 'minimal requirements' that future initiatives by patent offices should impose in order to warrant a more adequate, accurate and timely disclosure of patent ownership information.

The remainder of this paper is structured as follows. In the second paragraph we discuss the disclosure function of the patent system and highlight its deficiencies. In the third paragraph we examine the patent provisions concerning the disclosure of the identity of the initial applicant(s)

5 See Colleen Chien, 1, 1, The Who Owns What Problem in Patent Law, (2012), available at http://digitalcommons.law.scu.edu/facpubs/190 (stating that "patent ownership is a critical component of patent notice" and that "if patents provide the right to exclude, the public is entitled to know who might do the excluding". 
of a patent followed by an overview of the provisions with respect to the recordation of changes of ownership in paragraph four. In paragraph five, we discuss the USPTO's Notice on "Changes to Require Identification of Attributable Owner" followed by a proposal of recommendations for future initiatives aimed to improve the transparency of patent ownership in paragraph six. Finally, we present our concluding remarks in paragraph seven.

\section{The Notice Function of the Patent System}

\subsection{The relevance of disclosing patent information}

The most common justification for the patent system is a utilitarian one that defines the patent system as a property regime that aims to incentivize inventive effort that is desirable from a societal viewpoint yet may not be exerted - at least not at socially optimal rates - in its absence 6 Because the inventive process often results in outcomes that have the characteristics of a public good that is non-excludable and non-rivalrous, it enables actors other than the original inventor to reap the rewards of their inventions 7 If inventions can be imitated at a cost that is lower than the initial cost of creating them, original inventors may not be able to appropriate sufficient ex post rents that arise from their invention. As a result, inventors may have ample incentives to develop inventions, which results in lower levels of investment in research and development than what is socially desirable ${ }^{8}$ The primary role of the patent system is to mitigate against this underinvestment problem by granting inventors exclusivity over their inventions, allowing them to capture an adequate ex post return. By doing so, the patent system remedies the inefficiency of private markets to effectively stimulate and allocate investment into research and development in the presence of externalities.

However, granting inventors a temporary exclusive right to prevent others from practicing

${ }^{6}$ See Kenneth W. Dam, The Economic Underpinnings of Patent Law, 23, J. LEGAL STUD. 247, 247 (1999) ("The patent system prevents others from reaping where they have not sown and thereby promotes research and development (R\&D) investment in innovation. The patent law achieves this laudable end by creating property rights in inventions.); Roberto Mazzoleni \& Richard R. Nelson, The Benefits and Costs of Strong Patent Protection, 27 RES. POL. 273, 275 (1998) (suggesting that the main underlying justification of the patent system is that "patents are needed to provide firms with the requisite incentive to invent, and that this does justify the costs of the temporary monopoly their granting gives").

7 See Kenneth W. Dam, The Economic Underpinnings of Patent Law, 23, J. LEGAL STUD. 247, 247 (1999) (noting that "innovation is essentially the creation of information, which has different economic characteristics from goods."); Joseph E. Stiglitz, Knowledge as a Global Public Good, 308, 308 (1999) (characterizing public goods as having two distinct properties: "nonrivalrous consumption- the consumption of one individual does not detract from that of another- and nonexcludability-it is difficult if not impossible to exclude an individual from enjoying the good").

${ }^{8}$ See Janusz A. Ordover, A Patent System for Both Diffusion and Exclusion, 5 J. ECON. PERS. 43, 43 (1991) ("If the owners of knowledge-assets have only minimal property rights, their returns may not be high enough to recoup their initial investment, much less attain a sufficient return to compensate them for undertaking a risky project. As a result, the initial investment may not be undertaken, thereby harming dynamic efficiency"). 
- making, using, importing or selling - their inventions may come at a significant social cost. Patent protection may enable patentees to set a premium price that is well above the market price of their invention, especially for inventions that are difficult to substitute. Such monopoly pricing leads to an underutilization of the invention and disproportionately transfers wealth from consumers to the patentee. In order to compensate for this deadweight loss to society, the legislator imposes the requirement on patentees to give public notice of the subject matter for which patent protection is sought. This enables third parties to identify and understand patent rights that could potentially read on their inventions. The disclosure of inventions in patent documents - which we refer to as patent notice in the remainder of this article - is typically thought of as being part of a patent bargain as the quid pro quo of granting an exclusive right to inventors. The patent bargain metaphor's omnipresence within the patent law community is demonstrated by the US-courts advancing the quid pro quo rationale in a number of renowned US-court-cases 9

Whilst there is considerable disagreement among commentators regarding the role that patent notice should serve in shaping patent policy - with some denoting it as a central function of the patent system and others deeming it to be merely an ancillary objective at best the potential benefits to society of disclosing inventions in patent documents are universally recognized 10 Firstly, an effective patent notice facilitates subsequent - follow-on - invention by enabling other inventors to learn about the characteristics and potential applications of an invention ${ }^{11}$ This teaching function not only allows others to make, use and further develop an

\footnotetext{
9 See e.g. Bonito Boats, Inc. v. Thunder Craft Boats, Inc., 489 U.S. 141, 150-151 (1989) (“The federal patent system thus embodies a carefully crafted bargain for encouraging the creation and disclosure of new, useful and nonobvious advances in technology and design in return for the exclusive right to practice the invention for a period of years."); J.E.M. AG Supply, Inc. v. Pioneer Hi-Bred International, Inc., 534 U.S. 124, 142 (2001) ("The disclosure required by the Patent Act is the quid pro quo of the right to exclude.”); Eldred v. Ashcroft, 537 U.S. 186, 224 (2003) (“Complete disclosure as a precondition to the issuance of a patent is part of the quid pro quo that justifies the limited monopoly for the inventor as consideration for full and immediate access by the public when the limited time expires".); Pfaff v. Wells Electronics, Inc., 525 U.S. 55, 63 (1998) (stating that "the patent system represents a carefully crafted bargain that encourages both the creation and the public disclosure of new and useful advances in technology, in return for an exclusive monopoly for a limited period of time").

10 See e.g., Jeanne C. Fromer, Patent Disclosure, 94 IOWA L. REV. 539, 542 (2009) and FED. TRADE COMM'N, The Evolving IP market place: aligning patent notice and remedies with competition, ch. 3. 73, 75-80 (2011) for arguments in favor of considering patent notice as a central aim of the patent system and Alan Devlin, The Misunderstood Function of Disclosure in Patent Law, 23 HARV. J. L. \& TECH. 401, 411 (2010) and Benjamin N. Roin, The Disclosure Function of the Patent System (Or Lack Thereof), 118 HARV. L. REV. 2007, 2028 (2005) for arguments in favor of treating patent notice as an ancillary objective of the patent system. Whereas the former view advances that patent notice is an objective of the patent system that is equally important to offering incentives to promote invention, the latter view argues that no sacrifices should be made to the 'incentive objective' in the name of patent notice. Thus, the latter view does not challenge the view that patent notice should be an objective of the patent system, it merely states that as an objective it is less important than the incentive objective.

11 See Kewanee Oil. Co. v. Bicron Corp., 416 U.S. 470, 481 (1974) (“When a patent is granted and the information contained in it is circulated to the general public and those especially skilled in the trade, such additions to the general
} 
invention after the patent term, but also to be inspired by, invent around and build upon it during the patent term ${ }^{12}$ In addition, signaling the achievements of others helps inventors to avoid investments that would result in duplications of existing inventions. ${ }^{13}$ When the notice function is poorly served, the original inventor may very well be the only person who possesses sufficient knowledge to further build upon her invention. This is not desirable from a societal point of view, given that most inventions are continuations, combinations or re-combinations of the ideas, discoveries and concepts developed by parties other than the original inventor 14 Commentators often refer to Sir Isaac Newton's famous aphorism "If I have been able to see further, it is by standing on the shoulders of giants" and argue that "... in the current evolution of high technologies, almost all technical progress builds on a foundation provided by earlier inventors" 15 An effective patent notice enables to stand on the shoulders of giants by levelling the playing field between the original inventor and the public by reducing the 'information advantage' of original inventors.

Secondly, an effective patent notice serves to clarify the 'legal' boundaries of an invention, which is paramount to a more efficient allocation of investment in invention ${ }^{16}$ Knowing in detail the boundaries that define a claimed invention allows inventors to avoid inadvertent infringement upon the intellectual property of others and thus prevents unnecessary and wasteful litigation. By holding the users of technology liable for infringement regardless of whether it is intentional or not, the patent system assigns the burden of avoiding litigation to these users. Given that infringers face significant consequences upon infringement, it is imperative that tech-

store of knowledge are of such importance to the public weal that the Federal Government is willing to pay the high price of 17 years of exclusive use for its disclosure, which disclosure, it is assumed, will stimulate ideas and the eventual development of further significant advances in the art.").

12 See e.g. Jeanne C. Fromer, Patent Disclosure, 94 IOWA L. REV. 539, 541 (2009) ("patent disclosure indirectly stimulates future innovation by revealing the invention's design so that others can use it fruitfully when the patent term expires and design around, improve upon, or be inspired by the invention, even during the patent term.").

13 See Edmund W. Kitch, The Nature and Function of the Patent System, 20 J.L. \& ECON. 265, 278 (1977) (stating that "once a patent has been issued, other firms can learn of the innovative work of the patent holder and redirect their work so as not to duplicate work already done" and that "under a regime of trade secrecy, the competitive firm might never learn of a competitor's processes and would not learn of the technology incorporated in a new product until it was marketed. During this period, the investments made in a search for technology already invented by others is wasted.").

14 See W. Brian Arthur, The nature of technology: what it is and how it evolves, (2009) (describing the 'combinatorial evolution' of technology, thereby highlighting that new technologies do not come from nowhere but arise as combination of other technologies).

15 See Suzanne Scotchmer, Standing on the Shoulders of Giants: Cumulative Research and the Patent Law, 5 J. ECON. PERS. 29, 29 (1991) (contending that "most innovators stand on the shoulders of giants, and never more so than in the current evolution of high technologies, where almost all technical progress builds on a foundation provided by earlier innovators" and providing many examples of technologies that are improvements of earlier technologies.).

16 See Festo Corp. v. Shoketsu Kinzoku Co., 535 U.S. 722, 730-31 (2002) (holding that "The patent laws "promote the Progress of Science and useful Arts” by rewarding innovation with a temporary monopoly. U. S. Const., Art. I, § 8 , cl. 8. The monopoly is a property right; and like any property right, its boundaries should be clear. This clarity is essential to promote progress, because it enables efficient investment in innovation. A patent holder should know what he owns and the public should know what he does not."). 
nology users are enabled to identify and understand applicable patent rights with reasonable certainty and that such clearance efforts can be undertaken at a reasonable cost ${ }^{17}$ An effective patent notice limits the uncertainty regarding infringement liability by informing the public about the outer bounds of a patentee's right to exclude ${ }^{18}$ The lower this uncertainty, the less time and effort a third party needs to spend on resolving conflicts and the more it can focus on activities that the patent systems aims to incentivize 19

\subsection{The deficiencies of patent notice}

Although the benefits of an effective patent notice are certainly compelling in theory, empirical research concerning the effectiveness of patent notice has produced inconclusive results ${ }^{20}$ For example, based on a survey of US-inventors of patented inventions, Jaffe and his contributors found that less than five percent of the surveyed inventors considered patent documents to have had a significant influence on the development of their inventions ${ }^{21}$ On the other hand, Cohen and colleagues, based on a survey of the R\&D managers of large US-enterprises, found that more than half of the respondents considered patent documents to be at least moderately important for their ongoing R\&D projects ${ }^{22}$ Despite these seemingly mixed empirical results, there is a strong consensus among legal commentators that the potential benefits of disclosing

\footnotetext{
17 See FED. TRADE COMM'N, The Evolving IP Market Place: Aligning Patent Notice and Remedies With Competition ch.3. 73, 74 (2011) (stating that "under its strict liability regime, the patent system confers patent rights and assigns the burden of avoiding infringement to users; as a corollary, the system also needs to facilitate users' ability to identify and understand the patent rights at hand" and "fundamentally, an effective notice system, in which prospective technology users can ascertain applicable patent rights at reasonable cost and with reasonable certainty, is essential for patents to operate as a property system.").

18 See FED. TRADE COMM'N, The Evolving IP Market Place: Aligning Patent Notice and Remedies With Competition ch.3. 73, 75-76 (2011) (expressing that patent notice "helps third parties and patentees to avoid uncertainty as to their rights" and that "such uncertainty can greatly inhibit innovation and competition.").

19 See FED. TRADE COMM'N, Hearing on the Evolving IP Marketplace: Fulfilling the Patent System's Notice Function 123 (Mar. 19, 2009) (statement of David J. Kappos) (noting that a notice function that is not functioning well forces all participants to "...spend undue amounts of effort on dealing with conflict instead of employing people, investing in doing research and development to create more innovation."), available at https://www.ftc.gov/sites/default/files/documents/public_events/evolving-ip-marketplace/090319transcript.pdf.; Ibid at 132 (stating that "the lack of clarity around patent rights... routinely forces action to move away from technology areas, move into different technology areas, steer clear of innovations that [one would] otherwise want to invest in.").

20 See Lisa Larrimore Ouellette, Do Patents Disclose Useful Information?, 25 HARV. J. L. \& TECH. 546, 561-565 (2012) for a comprehensive overview of existing surveys of the value of patent disclosures.

${ }^{21}$ See Adam B. Jaffe, Manuel Trajtenberg \& Michael S. Fogarty, The Meaning of Patent Citations, in Adam B. Jaffe \& Manuel Trajtenberg, Patents, Citations and Innovation: A Window on the Knowledge Economy 379, 389-390 (2002).

22 See Wesley M. Cohen et. al., R\&D Spillovers, Patents and the Incentive to Innovate in Japan and the United States, 31 RES. POL'Y. 1349, 1362-1364 (2002); Lisa Larrimore Ouellette, Do Patents Disclose Useful Information?, 25 HARV. J. L. \& TECH. 546, 561-565 (2012) (highlighting that the results of the Cohen study have been interpreted very differently by various legal commentators).
} 
technological information through patent documents are not fully realized in practice ${ }^{23}$ In particular, commentators advance that existing legal requirements do not adequately encourage the authors of patent applications to include technological information that is useful to the public. Their arguments mainly center around three properties of the information contained in patents; its uniqueness, its completeness and its clarity.

Concerning uniqueness, the main argument raised is that the patent system does not encourage the dissemination of information that would otherwise not become publicly available 24 This argument is founded on the conjecture that some inventions are inherently more selfrevealing in nature than others and that it is the more self-revealing inventions for which patent protection is most suitable. After all, these inventions can be reverse-engineered with relative ease once they enter the public domain, whereas inventions that are not self-revealing are less vulnerable to such efforts and can often be protected effectively through secrecy ${ }^{25}$ Insofar as the patent system only encourages the disclosure of inventions that readily disclose themselves once they enter the public domain, patent documents do not convey information that third parties could not obtain through other channels. Therefore, patent documents may present the public with little unique information.

Although this argument is certainly compelling, it has been refuted on multiple grounds. First, many patented inventions never become commercially available, because patent rights themselves do by no means impose the requirement on patentees to practice their inventions. ${ }^{26}$ For these inventions the patent document may very well be the only source of information that

\footnotetext{
${ }^{23}$ See Lisa Larrimore Ouelette, Do Patents Disclose Useful Information?, 25 HARV. J. L. \& TECH. 546, 561-565 (2012) (arguing that the surveys that legal commentators refer to in order to support the strong that patents are not a useful source of information for inventors do not necessarily provide empirical evidence to support this strong claim.)

24 See Benjamin N. Roin, The Disclosure Function of the Patent System (Or Lack Thereof), 118 HARV. L. REV. 2007, 2015 (2005) (questioning the assumption that "when an inventor files for a patent, she discloses information to which the public would not otherwise have access in exchange for the exclusive rights to her invention").

${ }^{25}$ See Alan Devlin, The Misunderstood Function of Disclosure in Patent Law, 23 HARV. J. L. \& TECH. 401, 418 (2010) (suggesting that "other things being equal, innovators patent inventions that they believe are vulnerable to reverse engineering" and concluding that "the concerns of many commentators that a patent system without disclosure would cause information to remain hidden indefinitely are misplaced" and highlighting that "patent laws likely were not designed to appeal to the inventors of concealable technology, for whom trade secret is the avenue of greatest allure."); Benjamin N. Roin, The Disclosure Function of the Patent System (Or Lack Thereof), 118 HARV. L. REV. 2007, 2015 (2005) (stating that "the reason why many inventors file for a patent is that their secret will be disclosed to the public as soon as they begin using or selling their inventions." and "many inventions that are difficult to reverse engineer will never be patented because the inventor would be unable to detect infringement, rendering the patent of little value.").

26 See Jeanne C. Fromer, Patent Disclosure, 94 IOWA L. REV. 539, 545 (2009) (emphasizing that "the patent right is not an exclusive right to market or practice a particular invention"); Continental Paper Bag Co. v. Eastern Paper Bag Co., 210 U.S. 405, 429 (1908) (explicitly stating that “... exclusion may be said to have been of the very essence of the right conferred by the patent, as it is the privilege of any owner of property to use or not use it, without question of motive"); Kurt M. Saunders, Patent Nonuse and the Role of Public Interest as a Deterrent to Technology Suppression, 15 HARV. J.L. \& TECH. 389, 391 n.10 (2002) (referring to several empirical studies to support the claim that "approximately forty to ninety percent of issued patent are not used or licensed by the patentee.").
} 
is readily available to the public. Second, when inventions do become commercially available, the average time-to-market in most industries is considerably lengthier than the average time between the filing and publication of a patent application ${ }^{27}$ Thus, third parties often have access to the information that is enclosed in patent documents long before reverse-engineering efforts can even be thought of. Third, even if an invention is susceptible to successful reverseengineering, it may be less time-consuming and costly to retrieve information from patent documents ${ }^{28}$ Fourth, even though a patent document itself may not contain unique information, its existence may inspire the dissemination of relevant information about the invention through other channels ${ }^{29}$ An example of such 'peripheral disclosure' is an academic scientist whose employer only allows her to present or publish the results of her research after a patent has been applied for ${ }^{30}$ Finally, empirical studies reveal that inventors do not only seek patent protection for inventions that are self-revealing but also for those that are not ${ }^{31}$ This is a strong indication that the patent system does in fact encourage the disclosure of unique information that would otherwise remain secret.

Concerning completeness and clarity, commentators' main concern is that existing legal disclosure requirements do not provide sufficient incentives for patentees to adequately disclose their inventions. There is an inherent tension between the public interest for information to be disclosed as completely and clearly in patent documents as possible and the private interest of

\footnotetext{
27 See Benjamin N. Roin, The Disclosure Function of the Patent System (Or Lack Thereof), 118 HARV. L. REV. 2007, 2016 (2005) (noting that "in pharmaceuticals, for example, it takes years for most patented inventions to reach the market, and patent disclosures can therefore provide public access to information long before it could be reverse engineered from the final product").

${ }^{28}$ See Benjamin N. Roin, The Disclosure Function of the Patent System (Or Lack Thereof), 118 HARV. L. REV. 2007, 2017 (2005) (arguing that "because reverse engineering can be expensive, a patent disclosure may be more efficient at broadly disseminating information, specifically to companies outside the patentee's industry."); Jeanne C. Fromer, Patent Disclosure, 94 IOWA L. REV. 539, 558 (2009) (stating that "patentees regularly make commercially available inventions difficult to take apart and understand, increasing the cost and decreasing the effectiveness of reverse-engineering as a way to understand an invention."); Alan Devlin, The Misunderstood Function of Disclosure in Patent Law, 23 HARV. J. L. \& TECH. 401, 405 (2010) (noting that "when reverse engineering is necessary due only to a lack of effective patent disclosure, capital expended on such engineering is socially wasteful, even if the end result is otherwise desirable.").

${ }^{29}$ See FED. TRADE COMM'N, Hearing on the Evolving IP Marketplace: Recent Scholarship in Patent Markets 200201 (Apr. 17, 2009) (statement of Polk Wagner) (highlighting that "the fact that people patent means that they go on and they give papers or they produce products or they do other things that then provide the information about the innovation, even if the patent itself isn't a particularly great medium for transferring the technological knowledge").

30 See Jason Rantanen, Peripheral Disclosure, 74 U. PITT. L. REV. 1, 16-37 (2012) (defining peripheral disclosure as "the non-patent sharing of information... that is being provided by an inventor in a form other that the patent document... [and] that an inventor could not share with the public without losing some ability to monetize the invention under a regime relying on secrecy to appropriate the value of an invention" and providing several examples of peripheral disclosure).

31 See Alan Devlin, The Misunderstood Function of Disclosure in Patent Law, 23 HARV. J. L. \& TECH. 401, 432 (2010) (concluding that "the phenomenon of inventors patenting non-self-revealing technologies demonstrates that patent law's disclosure function continuous to have value in many instances" and mentioning three explanations for the existence of this phenomenon).
} 
patentees to limit the opportunities of third parties to appropriate rents from their inventions. The rationale underlying this tension is largely axiomatic. The more complete and clear the information conveyed in a patent document, the more it reveals about the inner workings and legal boundaries of an invention, and thus, the lower the costs of potential competitors of a patentee to invent around or build upon her invention. Patentees, therefore, have an incentive to withhold or obfuscate information that is relevant, necessary or even vital to fully understand the inner workings of their inventions and the limits of their rights thereto ${ }^{32}$ This disincentive is the reason why legal disclosure requirements are needed to warrant an adequate disclosure of inventions 33 Given that inventors have little to no incentives to disclose more information than strictly required, these requirements determine the amount and nature of the information that will be disclosed. Despite the strong statutory language of these requirements however, commentators regularly cite anecdotal evidence to support their claim that only few patents contain written descriptions that allow for the invention to be carried out by a third party. Whilst, some attribute this to an insufficient enforcement of existing requirements, others go as far as suggesting that these requirements allow for, if not, encourage the exclusion of relevant technological information from patent documents.

\section{Patent Notice and the Market for Patent Monetization}

\subsection{Patent notice as driver of technology transactions}

A third and often overlooked benefit of patent notice is that it can facilitate the transfer of technology which, according to economic commentators, has considerably gained in importance since the beginning of the 1990s. Although the utilitarian justification primarily highlights the importance of the patent system for getting inventions developed, increasing activity on 'markets for technology' has led commentators to recognize that the patent system may be equally important for getting these inventions put to use. There is an extensive economic scholarship suggesting that in today's knowledge-based economy the capabilities needed to develop inventions are increasingly removed from the capabilities that are needed for commercializing them ${ }^{34}$ Due to the increasing complexity of technologies and the globalization of markets it is

\footnotetext{
32 See Suzanne Scotchmer \& Jerry Green, Novelty and Disclosure in Patent Law, 21 RAND J. ECON. 131, 132 (1990) (noting that "disclosing technical information confers a positive externality on a firm's competitors, which the firm might want to avoid.").

33 See Alan Devlin, The Misunderstood Function of Disclosure in Patent Law, 23 HARV. J. L. \& TECH. 401, 419 (2010) (arguing that current disclosure requirements "... create a disincentive to seek patent protection by requiring inventors to reveal the inner working of their discoveries, thus reducing the cost to their rivals of recreating those inventions.").

34 See e.g. Ashish Arora et. al., Markets for Technology: The Economics of Innovation and Corporate Strategy ch.1. 1, 2 (2001) ("This vision of knowledge creation integrated with knowledge use has become inadequate for understanding economic growth in the twenty-first century. Over the past ten to fifteen years, there has been a rapid growth in a variety of arrangements for the exchange of technologies or technological services, ranging from $R \& D$ joint ventures
} 
often not feasible for a single firm to be the source of all innovative aspects of a product. A firm that initiates the development of an invention is not necessarily the one that is best positioned to bring it to the market. And even if a firm is able to successfully commercialize an invention it may not be able to oversee all of its potentially useful applications. As a result, innovation processes have become more 'open' in the sense that the pathway to innovation often transcends the boundaries of a single entity ${ }^{35}$ This trend is manifested in the development and growth of markets for technology where exchanges involve intermediate technological outputs rather than commercial end products. ${ }^{36}$

Markets for technology have the potential to become important drivers of economic growth and consumer welfare by allowing for a division of labor between the entities that invent and the entities that commercialize most efficiently ${ }^{37}$ The entities that do not possess the capabilities and resources that are needed to commercialize inventions can specialize in the development and supply of technology, whilst the entities that do possess these capabilities and resources no longer need to develop all their technologies in-house. By offering a pathway to innovation without commercialization, such specialization increases both the supply of technology and the competition among technologies by lowering the entry barriers for entities that do not have the resources to manufacture, market and distribute their inventions ${ }^{38}$ This is illustrated by the entry of many small-and medium-sized enterprises that make a profitable business as specialist suppliers of technology to larger manufacturing firms since the beginning of the 1990s. A greater supply of and competition among technologies not only leads to the development of qualitatively better and cheaper technologies but also to technologies that can be applied more widely and can be distributed to consumers faster ${ }^{39}$ In essence, a division of innovative labor

and partnerships to licensing and cross-licensing agreements, to contracted R\&D. Although we lack comprehensive empirical measures of the increase in such arrangements over time, all the available evidence suggests that the trade in technologies is more common than it was in the past.”); See Henry Chesbrough \& Marcel Bogers, Explicating Open Innovation: Clarifying an Emerging Paradigm for Understanding Innovation, in Henry Chesbrough et. al., New Frontiers in Open Innovation 1, 27 (2014) (observing that companies cannot afford to solely rely on their own R\&D in an era in which the sources of knowledge for innovation are widely distributed in the economy).

35 See Henry Chesbrough \& Marcel Bogers, Explicating Open Innovation: Clarifying an Emerging Paradigm for Understanding Innovation, in Henry Chesbrough et. al., New Frontiers in Open Innovation 1, 27 (2014) (defining open innovation as "a distributed innovation process based on purposively managed knowledge flows across organizational boundaries, using pecuniary and non-pecuniary mechanisms in line with each organization's business model.”).

36 See e.g. Ashish Arora et. al., Markets for Technology: The Economics of Innovation and Corporate Strategy ch.1. 1, 2 (2001).

37 See e.g. Ashish Arora et. al., Markets for Technology: The Economics of Innovation and Corporate Strategy ch.1. 1, 9 (2001) (contending that "technology markets are a precondition for the existence of specialized technology suppliers operating in vertical markets" and that "specialization and division of labor is a powerful determinant of industry and economic growth.”).

38 See FED. TRADE COMM'N, The Evolving IP Market Place: Aligning Patent Notice and Remedies With Competition ch.1. 31, 33 (2011).

39 See FED. TRADE COMM'N, The Evolving IP Market Place: Aligning Patent Notice and Remedies With Competition ch.1. 31, 33 (2011). 
allows for gains to be made from trading technologies, and the magnitude of these gains are dependent on the efficiency of markets for technology.

An effective patent notice can positively affect the functioning of these markets in two primary ways. First, by disclosing the subject matter of claimed inventions, patents signal the availability of technologies to potential buyers, licensees, investors and collaborators and bring these parties together with the owners of technologies. Second, patents define rights on intangible concepts making it easier for parties to negotiate and form contractual agreements. An effective patent notice helps to overcome what economists refer to as Arrow's information paradox ${ }^{40}$ Named after economist Kenneth Arrow, this paradox describes the inherent information asymmetry that exists between an entity expressing interest in a given technology and the proprietor of this technology. Whereas the former cannot assess the authenticity of the technology without having sufficiently detailed information about it, the latter has an incentive to disclose as little information as possible. Due to the non-excludable and non-rivalrous nature of public goods, the disclosure of too much information may reduce the interested party's willingness to pay and may erode the bargaining position of the proprietor. On the other hand, the disclosure of too little information may devalue the technology to a price level that the proprietor is not willing to accept because the interested party cannot determine whether the technology is genuine or not. As a result, both parties lose in this game and transactions that rationally should happen - those that would benefit both the proprietor and the interested party - may not materialize. This situation is more intuitively explained by a practitioner who draws parallels with the functioning of consumer markets:

\begin{abstract}
It's just like the situation where you're shopping for any kind of a product, and you're not sure if you're looking at the genuine thing, right? Whether it's a watch or a car or whatever, you wind up in conflict over the value of it because you don't have confidence in its authenticity. [...] "When we look at [a] watch we don't know whether it's really a Rolex, so, we're going to devalue that thing, right? And on both sides of the equation, if it's a genuine thing you're not going to get enough for it because of the devaluation factor. And on the other side, you're not willing to pay enough for it because you're concerned that it might not be genuine. So, ironically, I think sort of everybody loses in this equation. There is a tremendous amount of unproductive effort spent. And then the result winds up being suboptimal at the very end of all of that effort 41
\end{abstract}

Patents can remedy this situation by offering protection from misappropriation by third parties and encouraging inventors to disclose relevant information that they would otherwise have kept secret. Although patents do not necessarily simplify the valuation of inventions, they do at

\footnotetext{
40 See Kenneth J. Arrow, Economic Welfare and the Allocation of Resources for Invention, in 609 NAT'L BUREAU OF ECON. RES., The Rate and Direction Of Inventive Activity, (1962).

41 See Fed. Trade Comm'n, Hearing on the Evolving IP Marketplace: Fulfilling the Patent System's Notice Function 131-132 (Mar. 19, 2009) (statement of David J. Kappos).
} 
least provide a starting point for negotiations between technology owners and interested third parties. As a result, patents are often an integral part of technology exchanges and have as such become transactable pieces themselves.

\subsection{The significance of transparent patent ownership information}

The adequate disclosure of an invention for which patent protection is sought is one of the patentability requirements commonly imposed by patent offices ${ }^{42}$ Although there are differences between the procedural requirements that patent offices impose, they generally require that an acclaimed invention is described in a manner sufficiently clear and complete for it to be carried out by a person skilled in the art ${ }^{43} \mathrm{~A}$ patent document should at least contain one or more claims that define the critical elements of an invention, such that the patent examiner can assess whether it meets the other patentability requirements of novelty, non-obviousness/inventive step and usefulness/having an industrial application ${ }^{44}$ The requirement to codify inventions conform the standards of patent offices is a strict one in the sense that a failure to do so has serious implications for the parties having an ownership interest in a (prospective) patent. It can provide grounds both for the refusal of a patent application during the pre-grant stage as well as for the revocation of a patent during the post-grant stage. The requirement for an adequate disclosure of inventions is therefore a powerful instrument for reducing the uncertainty about the function and characteristics of patent-protected technologies. Reducing this uncertainty lowers the aforementioned information asymmetry that characterizes markets for technology.

For a technology transfer to occur though, the detailed information describing an invention must be complemented with information concerning the ownership interest in this invention. Hence, purposive technology transactions can only be established by a formal agreement of

\footnotetext{
42 See WIPO, WIPO Intellectual Property Handbook: Policy, Law and Use, 21 (2004).

43 See for instance Art. 112 of the United States Code (USC) Title 35 requires that the specification of an invention “... shall contain a written description of the invention, and of the manner and process of making and using it, in such full, clear, concise, and exact terms as to enable any person skilled in the art to which it pertains, or with which it is most nearly connected, to make and use the same, and shall set forth the best mode contemplated by the inventor of carrying out his invention...". Art. 83 of the Convention on the Grant of European Patents (European Patent Convention) of 5 October 1973, Munich (EPC): "The European patent application shall disclose the invention in a manner sufficiently clear and complete for it to be carried out by a person skilled in the art". . See also Margarete Singer and Dieter Stauder, The European Patent Convention: A Commentary: Procedural patent law, article 90 to article 178. Sweet and Maxwell, London, p. 355; Halpern SW, Seymore SB, Port KL (2015) Fundamentals of United States intellectual property law: copyright, patent, trademark. Wolters Kluwer, Alphen aan den Rijn, p. 197.

44 See e.g. Art. 27(1) Agreement on Trade Related Intellectual Property Rights 1994 (TRIPS), Art. 52(1) EPC, 35 U.S.C. 101, 35 U.S.C. 102, 35 U.S.C. 103. See also 38 WIPO (2004) supra n 43, p. 17-21; Cottier T, Vron P (2015) Concise international and European IP law: TRIPS, Paris Convention, European enforcement and Transfer of technology. Kluwer Law International, Alphen aan den Rijn, p. 92; Singer and Stauder (2003), supra n 44, p. 64; Halpern et al. (2011), supra n 44, p. 196).
} 
some sort with the actual owner(s) of technologies. Therefore, even the most detailed information regarding the functions and characteristics of a technology is of little use to an interested buyer or licensee, unless the owner(s) of that technology is known to her. This by default demands that the potential buyer or licensee can identify the owner(s) of an invention ex ante the transaction. Transparent ownership information is generally thought of as being part of the 'social contract' between a patentee and society and providing accurate patent ownership information is therefore an obligation and not a matter of choice. ${ }_{45}^{45}$ Patent authorities generally impose rules that require for the owner of an application for an original patent to be established when the original application is filed. The original applicant is presumed to be the owner of an application for an original patent and any patent that may be issued therefrom unless she assigns her ownership rights to another entity. The original applicant can exercise this right either pre-grant or post-grant and there is in principle no limit to the number of times that the ownership of a patent can change. It is this right to assign that provides the legal foundation for the transferability of patent-protected technologies.

However, commentators have raised concerns that suggest that the requirements for the registration of assignments as currently imposed by patent authorities and the enforcement thereof are ineffective to an extent that they are detrimental to the transparency of ownership. It has even been suggested that a lack of transparency of ownership has become a competitive tool for entities that are commonly associated with abusing the patent system for financial gain. Most notably, based on a thorough analysis of the activities of the well-known patent assertion entity - Intellectual Ventures - Ewing and Feldman conclude that the “...current laws provide limited opportunities for identifying and tracking activity in... [technology markets] ... and many opportunities for hiding..." ${ }^{46}$ As an example, they describe a case in which Intellectual Ventures recorded a change of ownership for a patent only 2,506 days after the date that the agreement had been executed. This effectively means that Intellectual Ventures could not be identified as the owner of the patent that had been assigned to it for a period of almost seven years. Although this case might be considered extreme, in a detailed description of assignments recorded with the USPTO, Marco et. al. show that relatively long time-lags between the execution and recordation of ownership changes are certainly not an exception ${ }^{47}$ They note that although a timely recordation with the USPTO should, in principle, occur at the latest three months after the date of execution, the average time lag between execution and recordation amounts to 182 days and

\footnotetext{
45 See Colleen Chien, The Who Owns What Problem in Patent Law, (2012), 1,1 available at http://digitalcommons.law.scu.edu/facpubs/190 (stating that "asking applicants and patentees "who owns it?" in order to provide this information to the public is well within the scope and statute and the [USPTO's] reasonable interpretation of it" and "asking for changes in ownership to be provided in the course of other communication with the patent office (office actions, maintenance fees, etc.) is a sensible and minimally burdensome way of getting it").

46 See Tom Ewing and Robin Feldman, The Giants Among Us, STAN. TECH. L. REV. 1, 37 (2012).

47 See Alan Marco et. al., The USPTO Patent Assignment Dataset: Descriptions and Analysis, USPTO Working Paper No. 2015-2. (2015), available at: https://ssrn.com/abstract=2849634.
} 
is increasing since 2005 .

Although these findings strongly suggest that not all assignments are recorded in a timely fashion, they are likely to capture only a share of the lack of transparency of ownership in technology markets. To the extent that current patent provisions are indeed ineffective for monitoring ownership changes and provide opportunities for entities that want to hide their ownership, these entities might opt not to report an ownership change at all ${ }^{48}$ In other words, the total population of patent ownership changes may be unobservable, which limits the inferences that can be made on the basis of recent applications of patent assignments as indicators of technology transfer in economic literature ${ }^{49}$ In economic terms, there may be a selection bias if recorded assignments are not representative of the whole population of assignments. The notion that ownership changes may be reported relatively late after their execution date or may not be reported at all implies that the likelihood of identifying the actual owner(s) of a technology for which patent protection is sought, may be considerably lower once the ownership of this technology has been assigned. Thus, somewhat paradoxically, whilst the adequate disclosure of ownership enables transactions of patent-protected technologies, such transactions might in turn have a negative effect on the adequate disclosure of subsequent ownership. Given that patent authorities are the ones responsible for regulating and monitoring the registration of patent ownership changes, this observation warrants a thorough examination of their patent provisions concerning the registration of ownership changes and the enforcement thereof.

Therefore, in the two subsequent paragraphs we present a legal comparative analysis of the requirements that six different patent authorities impose concerning the recordation of patent ownership changes. To provide a complete understanding of the rationale behind these requirements we start our analysis in section three with an examination of patent provisions concerning the establishment of the initial applicant(s) of a patent prior to and at the date of grant. Hence, requirements concerning the recordation of ownership changes are likely to be better understood in light of the ways in which patent authorities establish the identity of the initial applicant(s) of a patent. In section four we focus specifically on patent provisions with regard to patent ownership changes that may occur both prior to and after grant. We include five national patent offices - the United States Patent and Trademark Office (hereafter USPTO), the Japanese Patent Office (hereafter JPO), the French Institut National de la Propriété Industrielle

\footnotetext{
48 The USPTO itself acknowledges this issue, by courtesy of the following disclaimer on the website of its online repository of assignment documents; “...When relevant information is given to the USPTO to be recorded in the USPTO's assignment database, the USPTO simply puts the information on the public record and does not verify the validity of the information. Recordation is a ministerial function-the USPTO neither makes a determination of the legality of the transaction nor the right of the submitting party to take the action...". See http://assignment.uspto.gov.

${ }^{49}$ For example, by utilizing the USPTO Patent Assignment Database, Serrano CJ, The dynamics of the transfer and renewal of patents. RAND J. Econ. 41, 686. explores general patterns of technology trading whilst Galasso, Schankerman and Serrano, 2011, explore the relation be- tween technology trading and the enforcement of patent rights and Serrano (2011) estimates the gains from trade on markets for technology.
} 
(hereafter INPI), the German Patent and Trade Mark Office (hereafter DPMA) and the United Kingdom Intellectual Property Office (hereafter UK IPO) - and one regional patent office - the European Patent Office (hereafter EPO) - in our analysis. These patent offices were selected provided that they are the most active patent offices in terms of patents granted and are known to exert variation in legal provisions concerning patent-related matters.

\section{The Establishment of the Initial Applicant(s)}

\subsection{The right to initiate a patent application}

Prior to analyzing in depth, the requirement to disclose the identity of the initial patent applicant(s), it is essential to understand how the patent offices under study establish who has the right to initiate a patent application and thus consequently become a patent applicant. Each patent office has dedicated provisions in place that specify who has the right to apply for a patent and depending on the patent office, three aspects are taken into account in order to define whether a person has the right to apply for a patent: (i) whether the person is the inventor or assignee; (ii) whether the person is a natural or a legal person and (iii) whether the person meets certain residence or nationality requirements.

Concerning the first aspect, the regulations in all jurisdictions under study indicate that a patent application can be initiated either by an inventor herself or by her successor in title (e.g. an assignee) ${ }_{50}^{50}$ Nevertheless, if an applicant is not an original inventor, an inventor has the right to be mentioned as an inventor ${ }^{51}$ Moreover, the request for grant of a patent in some jurisdictions needs to contain the designation of the inventor/inventor's oath or declaration which allows to identify an inventor ${ }^{52}$ If an applicant is not an inventor or is not the sole inventor, the

\footnotetext{
50 See Art. 60(1) EPC; 37 Code of Federal Regulations (C.F.R) 1.42; 35 U.S.C. 118; Art. 29(1) of the Japanese Patent Act (JPA); Art. 33(1) JPA; Art. 34 JPA; L611-6 of the French IP Code (CPI); Section 6 of the German Patent Law (PatG); Section 7(2) of the UK Patent Act (UK PA). See also Singer and Stauder (2003), supra n 44, p. 184; Haedicke M, Timmann H (2014) Patent law: a handbook on European and German patent law. Beck, Mnchen, p. 246 and 344; Doi T (2007). Japan. In: Vanhees H, Blanpain R (eds.) Intellectual Property. Kluwer Law International, The Hague, p. 104; Kawaguchi H (2007) The essentials of Japanese patent law: cases and practice. Kluwer Law International, Alphen aan den Rijn, p. 36; Pollaud-Dulian F (2011) Proprit intellectuelle: la proprit industrielle. Economica, Paris, p. 212; Torremans P (2008) Holyoak and Torremans: intellectual property law. Oxford university press, Oxford, p 94; Thorley S, Miller R, Campbell D, Burkill G, Birss C (2006) Terrell on the law of patents. Sweet and Maxwell, London, p. 42.

${ }^{51}$ In spite of that assignment, an inventor has the right to be mentioned as an inventor in the patent, e.g. Art. 4ter Paris Convention for the Property of Industrial Property; Art. 62 EPC; 25 U.S.C. 115 (a); Art. 36(1)(ii) JPA; L611-9 CPI; Section 37 PatG; Section 63 PatG; Section 13 UK PA; Section 10 UK Patent Regulations (PRs). See also Cottier et al. (2015), supra n 45, p. 242; Singer and Stauder (2003), supra n 44, p. 200; Doi (2007), supra n 50, p. 105; Pollaud-Dulian (2011), supra n 50, p. 213; Haedicke and Timmann (2014), supra n 50, p. 245; Thorley et. al. (2006), supra n 50, p. 45.

52 See for instance Art. 81 EPC; Rule 19 EPC Regulations; 35 U.S.C. 115; Section 37 PatG; Rule 10 UK PRs; point 7 of the UK IPO Patent Form 7 Statement of inventorship and of right to grant of a patent. See also Guidelines for Examination in the European Patent Office 2015 (EPO Guidelines for Examination), A-III, 5.3; Haedicke and Timmann
} 
$\mathrm{EPO}$, for instance, has to communicate to a designated inventor information about the applicant and her application 53 which is meant to prevent applications being made without consent of the inventor. In case an invention was developed by more than one inventor and/or was assigned to more than one person, the application can be filed jointly 54 It is important to note that prior to the implementation of the America Invents Act in 2012, a patent application by the USPTO could only be filed by an inventor. Currently, the USPTO identifies three scenarios: the filing of an application by an inventor 55 , the filing of an application by a party other than the inventor (by an applicant-assignee $\sqrt{56}$ and the issuance of a patent to a non-applicant assignee ${ }^{57}$. Prior to the reform a patent application could only be filed by an inventor or on behalf of the inventor 58

Considering that the right to apply for a patent can be assigned from an inventor (a natural person) to another natural person or a legal person (e.g. organization whose employee developed an invention), the regulations in all six jurisdictions specify that a patent application can be filed not only by a natural person but also by a legal person 59 A typical example of an assignment of a patent application from a natural person to a legal person is the obligation of an inventor-employee to assign her rights to apply for patent protection to her employer ${ }^{60}$ This requirement is generally specified in an employment agreement.

Finally, some patent offices take into consideration the residence or nationality requirements when establishing whether an inventor or assignee has the right to apply for a patent. For instance, the JPO does not allow foreign nationals who do not have a residence or domicile in Japan to file a patent application ${ }^{61}$ However, the filing is allowed in case a patent applicant satisfies the requirement of reciprocity ${ }^{62}$ In some jurisdictions it is foreseen that the patent

(2014), supra n 50, p. 386; Thorley et. al. (2006), supra n 50, p. 45.

53 See Rule 19 (3) EPC Regulations. See also EPO Guidelines for Examination, A-III, 5.4; Haedicke and Timmann (2014), supra n 50, p. 245.

54 See Art. 59 EPC; 37 C.F.R. 1.42; 37 C.F.R. 1.45; Art. 38 JPA; L613-29 CPI; Section 6 PatG; Section 7(1) UK PA. See also EPO Guidelines for Examination, A-II, 2; Singer and Stauder (2003), supra n 44, p. 181 and 186; Doi (2007), supra n 50, p. 107; Pollaud-Dulian (2011), supra n 50, p. 214; Haedicke and Timmann (2014), supra 50, p. 248; Torremans (2008), supra n 50, .p 94; Thorley et al. (2006), supra n 50, p. 42.

55 See 35 USC 111.

56 See 35 USC 118.

57 see 35 USC 152.

58 See 35 USC 118 (pre-AIA).

59 See Art. 58 EPC; Section 4(2) PatV. See also EPO Guidelines for Examination, A-II, 2; Singer and Stauder (2003), supra n 44, p. 180; Haedicke and Timmann (2014), supra n 50, p. 344; Kawaguchi (2007), supra n 50, p. 35.

60 See Art. 60(1) EPC; Art 35(2) JPA; L611-7 CPI; Section 13 of the Gesetz uber Arbeitnehmererfindungen 1957 (ArbnErfG); Section 29 UK PA. See also Singer and Stauder (2003), supra n 44, p. 187; Doi (2007), supra 45, p. 104; Kawaguchi (2007), supra n 50, p. 36; Pollaud-Dulian (2011), supra n 50, p. 223; Torremans (2008), supra n 50, p 95; Thorley et. al. (2006), supra n 50, p. 43.

61 See Art. 25 JPA. See also Doi (2007), supra n 50, p. 104; Kawaguchi (2007), supra n 50, p. 35.

62 See Art. 25 JPA, Doi (2007), supra n 50, p. 104: "Article 25 provides the status of aliens as follows: an alien who has neither domicile nor residence (a business establishment, in the case of a legal entity) in Japan shall not enjoy patent rights or other rights relating to patents, except in cases that come under the following items: (i) where the country of his nationality entitles Japanese nationals to enjoy patent rights or other rights relating to patents under same conditions as 
applicant, who is not a resident or a national of the country in question may appoint an agent (e.g. a lawyer or a patent attorney) to represent her in that particular country 63

\subsection{Determining the identity of the initial patent applicant(s)}

\subsubsection{Information requirements to accord a filing date}

A review of the procedures of the patent offices under study to accord a filing date reveals that in all six jurisdictions an applicant in general does not have to provide detailed information about her identity at the initial patent application stage. Although there are some minor differences between offices regarding the scope of the requirements to accord a filing date, the requirement to provide the necessary information that allows for the applicant to be contacted is the only requirement that needs to be fulfilled in order to initiate the patent application process.

Whereas no specific requirement to provide information regarding the identity of a patent applicant to accord a filing date is advanced by the USPTO, it is indicated in the regulations that "when filing an application, a correspondence address must be set forth in either an application data sheet, or elsewhere, in a clearly identifiable manner, in any paper submitted with an application filing" 64 If the applicant does not provide a correspondence address, the USPTO "may treat the mailing address of the first named inventor as the correspondence address" 65 The EPO does explicitly include the requirement to provide information regarding the identity of a patent applicant and requests the provision of "information identifying the applicant or allowing the applicant to be contacted" ${ }^{66}$ According to the Guidelines for Examination in the $\mathrm{EPO}$, "any kind of information which allows the applicant to be contacted will be considered to fulfill requirement in particular: (a) the name and address of the applicant's representative, (b) a fax number, (c) a PO box number" 67

The same level of information is requested by the INP 68 and the UK IPQ 69 The UK IPO carefully specifies in its Formalities Manual which parts of the provided form "Request for grant of a patent" (Form 1 ${ }^{70}$ need to be filled in to provide sufficient information to "identify the its nationals; (ii) where the country of his nationality is prepared to entitle Japanese nationals to enjoy patent rights or other rights related to patents under the same conditions as its nationals, if Japan entitles the nationals of that country to enjoy patent rights or other rights relating to patents; (iii) where otherwise provided in a treaty".

63 See for instance Section 25 PatG.

64 See 37 CFR $1.33(\mathrm{a})$.

65 See 37 CFR $1.33(\mathrm{a})$.

66 See Rule 40(1)(b) EPC.

67 See the EPO Guidelines for Examination, A-II, 4.1.2. Moreover, in case there are multiple applicants, it will be considered sufficient if information concerning only one of the applicants is provided (EPO Guidelines for Examination, A-II, 4.1.2).

68 See L612-2 CPI. See also Pollaud-Dulian 2011, p. 242.

69 See Section 15(1) UK PA. See also Torremans 2008, p. 48.

${ }^{70} \mathrm{~F} 1$ is Patents Form 1 'Request for grant of a patent'. 
person applying for a patent" and "enable that person to be contacted by the patent office, 7172 In practice, however, the UK IPO may accord a filing date even if not all the aforementioned requirements are fulfilled at the time of filing. It can be sufficient to provide contact information such as "name, e-mail, telephone number and/or mobile number" 73 In addition to the requirements of INPI and the UK IPO, the DPMA also prescribes to provide the name of the applicant and file a request for the grant of a patent, in which additional information about the identity of a patent applicant must be provided 74

\subsubsection{Information requirements to initiate the formal examination of patents}

At the stage of formal examination patent examiners require more detailed information about the identity of an applicant at the initial date of application. Generally, the document that applicants need to provide to examiners is referred to as a request ${ }^{75}$ except for the USPTO, where the term used is the application data sheet 76 An important part of the content of the request/ data sheet is the identification of an applicant 77

72 In particular, sufficient information includes: "the name and address of the applicant in part 2 of the F1; the name and address or other contact details for an agent or an address for service in part 4 of the F1; an e-mail address, telephone number or fax number of a contact point for the applicant recorded in part 12 of F1". See UK IPO Formalities Manual, 2.05. Similar to the UK IPO, the DPMA prescribes to fill in the provided form that specifies the exact amount of information with regard to the identity of the applicant in Section 4 PatV.

73 See the UK IPO Manual of Patent Practice, Section 15, p. 2. Moreover, if the application is submitted without a name and address of an applicant or an agent but a contact phone number, e-mail address or other contact details were indicated, the UK IPO will try to contact the applicant in order to grant a filing date (UK IPO Formalities Manual, 2.06)

${ }^{74}$ See Section 35(1) PatG. See also Haedicke and Timmann (2014), supra n 50, p. 464 and 476.

75 See Art. 78(1)(a) EPC; Rule 57(b) EPC Regulations. See also Haedicke and Timmann (2014), supra n 50, p. 372.; Art. 36 (1) JPA; R 612-3 CPI; Section 34(3) PatG; Section 14(2) UK PA. The components of the request may vary depending on the patent office (Art. 4(1) PCT; Art. 4 PCT Regulations; Rule 41(1) EPC Regulations; 37 CFR 1.76; Art. 36(1) JPA; R612-10 CPI; Section 4 PatV; Section 12(1) UK PRs. See Haedicke and Timmann (2014), supra n 50, p. 372 and 468; Doi (2007), supra n 50, p. 105; Kawaguchi (2007), supra n 50, p. 173; Pollaud-Dulian (2011), supra n 50, p. 246.

76 The similarity in the requirements in different patent offices can again be explained by the fact that the Patent Law Treaty 2000 (PLT) harmonized the maximum amount of formal requirements by making a reference to the ones applicable to the international applications under the Patent Cooperation Treaty 1970 (Art. 6(1) PLT). The logic cannot be applicable to Japan and Germany since they did not ratify the PLT but it is visible that Germany patent office was still influenced by the PCT standard. The PCT, among other documents, obliges a patent applicant to submit a request (Art. 3(2) PCT). The request consists of in total five components, among which one requires to provide the name of and other prescribed data concerning the applicant and the agent (if any) (Art. 4(1)(iii) PCT). In particular, the applicant needs to indicate the persons name, her address and her nationality and residence (Rule 4.5 PCT Regulations). When the applicant is a natural person her name shall be indicated by the persons family name and given name(s), the family name being indicated before the given name(s) (Art. 4.4(a) PCT Regulations). A legal entity is required to indicate its full, official designations (Art. 4.4(b) PCT Regulations). If there are multiple applicants, the indication of the address of only one of them is sufficient (Art. 4.4(d) PCT Regulations). To simplify the procedure the PCT provides a patent applicant with a special request form, which contains all the above-mentioned components (PCT Request Form PCT/RO/101).

77 See 37 CFR 1.76; 41(2) EPC Regulations; 36(1) JPA; R612-10 CPI; Section 4 PatV; 12(1) UK PRs.
} 
At the USPTO, the application data sheet ${ }^{78}$ should be provided when an application is filed by the person other than an inventor, regardless of whether it is a provisional or nonprovisional application ${ }^{79}$ The data sheet contains information about the applicant ${ }^{80}$ which "includes the name (either natural or legal person) and address of the legal representative, assignee, person to whom the inventor is under an obligation to assign the invention, or person who otherwise shows sufficient proprietary interest in the matter" ${ }^{81}$ To facilitate the application process, the UPSTO provides an applicant with an application data sheet form 82 However, if a nonprovisional application is submitted by an inventor, it suffices to only file an inventor's oath or declaration, which focuses on disclosing the name of the inventor ${ }^{83}$ The document needs to identify "each inventor by his or her legal name; and a mailing address where the inventor customarily receives mail, and residence, if an inventor lives at a location which is different from where the inventor customarily receives mail, for each inventor" ${ }^{84}$ For a provisional patent application, instead of the inventor's oath or declaration, the applicant is obliged to include a cover shee ${ }^{85}$ or a cover letter which specifies that the application is a provisional application ${ }^{86}$ If those documents are not provided, the application will be treated as a nonprovisional one 87 Both documents require to identify an inventor.

The EPO, JPO, INPI, DPMA and UK IPO also provide clear instructions concerning the information about the identity of an applicant that has to be provided in the request. Similar to the application data sheet form of the USPTO, these offices provide applicants with a special 'request form' that they need to fill in, in order to facilitate the application process and make sure that the information provided by every applicant is similar ${ }^{88}$ Deviating from the USPTO, this request form has to be sent regardless of whether the application is initiated by an inventor herself or not. Generally, patent applicants need to provide their names, addresses

\footnotetext{
78 See 37 CFR 1.76.

79 See 37 CFR 1.46(b). The application data sheet also "must be submitted when required by $\S 1.55$ or 1.78 to claim priority to or the benefit of a prior-filed application under 35 U.S.C. 119, 120, 121, 365, or 386" (37 CFR 1.46(a)).

80 See 37 CFR $1.76(\mathrm{~b})$.

81 See 37 CFR 1.76(b)(7).

82 See http://www.uspto.gov/sites/default/files/documents/aia0014.pdf

83 See 35 USC 111(a)(2)(c); 35 USC 115, 37 CFR 1.63.

84 See 37 CFR 1.63(b). This information has to be supplied, unless the indicated information is provided in an application data sheet (37 CFR 1.76).

85 The cover sheet identifies: (i) the application as a provisional, (ii) the name or names of the inventor or inventor or inventors, (iii) the residence of each named inventor, (iv) the title of the invention, (v) the name and registration number of the attorney or agent (if applicable), (vii) the correspondence address, and (viii) the name of the US Government agency and Government contract number. 37 CFR 1.51(c). Similar to an application data sheet the USPTO provides a cover sheet form.

86 See 37 CFR $1.53(\mathrm{c})(1)$.

87 See 37 CFR $1.53(\mathrm{c})(1)$.

88 See EPO - Request for grant of a European patent Form 1001., INPI - La requête en délivrance, DPMA Antrag auf Erteilung eines Patents, UK IPO Request for grant of a patent Form 1.
} 
and nationality, residence or principle place of business 89 When it comes to the identity of an applicant, nearly all patent offices distinguish between information that a natural person and a legal person need to provide. ${ }^{90}$ Ultimately, at the stage of formal examination every patent office under study requests the provision of a sufficient detail of information that allows to identify and contact the initial patent applicant. Moreover, most patent offices require to disclose information concerning the representatives/agents of the initial applicant as well 91

\subsection{The failure to establish an initial applicant}

In case there are any deficiencies in the submitted documents, either during the preliminary examination to accord a filing date or during the examination of formal requirements, patent applicants are generally allowed to correct these deficiencies within a specified time frame 92 The accordance of a filing date is considered as the first step of the examination process, and, therefore, a patent office will not proceed with the examination before a filing date is accorded. For instance, the USPTO will notify a patent applicant about the need to provide the required information in case some information is missing and request the patent applicant to provide the missing information within two months from the receipt of the notification ${ }^{93}$ In case of failure to provide the necessary documents after the expiration of this time period, the patent application will be withdrawn ${ }^{94}$ If the applicant complies with the requirements within two months, the USPTO will accord a filing date.

Identical procedures are established at the EPO, the INPI, the UK IPO and the DPMA 95 However, the time period within which an applicant needs to provide required information varies. The EPO, the INPI and the UK IPO, similarly to the USPTO, request the corrected documents to be submitted within two months from the receipt of the notification ${ }^{96}$ whereas the

\footnotetext{
89 See 41(2)(c) EPC Regulations: 'the name, address and nationality of the applicant and the State in which his residence or principle place of business in located'; 36(1) JPA: 'the name or appellation of the applicant and his domicile or residence'; R612-10(4) CPI: 'the surname and name(s) of the applicant, his nationality, his place of residence or od business'; Section 4 PatV: 'information on the applicant'; 12(1) UK PRS 'full name, address and postcode of the applicant or of each applicant'. See also the mentioned above forms.

${ }^{90}$ Natural persons must indicate their family name and a given name, whereas legal persons must indicate their full official designations. The address must include all the relevant administrative units, including the house number and postal code. The EPO additionally asks for the correspondence address. The applicants are also asked to provide their phone number, email and fax. Rule 41(2)(c) EPC Regulations; Section 4 (1)(a) PatV. See also the request forms.

91 See for instance identified request forms, Rule 41 (2)(d) EPC Regulations.

92 See 37 CFR 1.53(b); 37 CFR 1.53(c); Art. 90 (4) EPC; Rule 55 and Rule 58 EPC Regulations; R612-8 CPI; R612-45 CPI; Section 35 (2,3) PatG; Section 42 PatG; Section 15(3) UK PA; Section 15A(6) UK PA; Section 12(2,3,9) UK PRs; Section 18 UK PRs. See also WIPO (2004), supra n 43, p. 25.

93 See 37 CFR 1.53(e)(1); 37 CFR 1.181(f).

94 See 37 CFR $1.53(\mathrm{e})(3)$.

95 See Art. 90(4) EPC; Rule 55 EPC; R612-8 CPI; Section 35(2)(3) PatG; Section 15(3) UK PA. See also Haedicke and Timmann (2014), supra n 50, p. 404 and 476; Pollaud-Dulian (2011), supra 50, p. 242. The JPO does not have a separate procedure of establishing a filing date.

96 See Rule 55 EPC; R612-8 CPI; Section 35(2)(3) PatG; Section 12(3, 9) UK PRs.
} 
DPMA limits the time period to one month. ${ }^{97}$ The withdrawal of the application is also foreseen in case of non-compliance with the requirement 98 If the applicant complies with the requirements within the prescribed time period, the filing date will be accorded the date of the receipt by the patent office of all required corrections. 99

It is noteworthy that, despite the existing mechanism of correcting deficiencies, the issue of the identification of an applicant is unlikely to be subject of the correction at this stage of the examination process. In particular, as aforementioned, the USPTO does not even denote the document identifying an applicant as one that needs to be filed to accord a filing date. The EPO specifically excludes the failure to provide information identifying the applicant or allowing the applicant to be contacted from the ones that are subject to notification ${ }^{100}$ Similar to the EPO, the DPMA only refer to missing parts in the description and drawings, no reference is made to the missing parts in the request or failure to provide the name of the applicant ${ }^{101}$ Arguably this lack of attention to the identification of an applicant can be explained by the fact that in case the basic contact information is not provided then it is evident that it is not possible to continue the examination since no information can be transmitted to the patent applicant from the patent office. Thus, it is in the interest of the applicant to provide sufficient information enabling her to be contacted at this stage of the application process and it is unlikely that the applicant will deliberately not provide this limited amount of information to the patent office. Complete information is requested at the latter stage of examination. Consequently, potential deficiencies with regard to the identification of patent applicants can be corrected and completed during that stage.

In general, in order to successfully complete the formal examination of a patent application, a patent applicant has to satisfy all patent application requirements. If some requirements are missing or incomplete, the USPTO notifies an applicant and gives her the opportunity to correct the defects within specified time limits ${ }^{102}$ If an applicant fails to correct the identified deficiencies the application will be considered withdrawn ${ }^{103}$ The EPO, the INPI, the DPMA and the UK IPO also requests applicants to correct any deficiency ${ }^{104}$, generally within the time limit of two

\footnotetext{
97 See Section 35(2)(3) PatG.

98 See Art. 90(2) EPC, R612-8 CPI, Section 12(3) UK PRs.

99 See Art. 5(4)(a) PLT; Art. 11(2)(b) PCT; Art. 90(5) EPC; Rule 55 EPC Regulations; 15(4) UK PA.

100 See Rule 55 EPC Regulations.

101 See Section 35(2)(3) PatG.

102 See CFR 37 CFR 1.53(f)(1); 37 CFR 1.53(g)(1). It must be noted that the USPTO indicated that the applicant will be given a period of time but the exact time is not specified in the provisions.

103 See CFR 37 CFR 1.53(f)(1); 37 CFR 1.53(g)(1).

104 See Art. 90(5) EPC; Section 45(1) PatG; Section 15A UK PA; Section 12(2) UK PA (the UK IPO specif- ically focuses on the identification of a patent applicant). See also Haedicke and Timmann (2014), supra 50, p. 373 and 469.
} 
months ${ }^{105}$ The non-compliance with the request will lead to a refusal of the application 106 Since the identification of a patent applicant is part of the patent application requirements, the non-sufficient communication of this information may lead to refusal of the application. Thus, applicants are incentivized to timely submit the required information to avoid these negative consequences. This strict approach ensures that patent offices collect sufficient information about patent applicants.

\subsection{The disclosure of the identity of initial applicants to the public}

Patent offices not only collect information about the identity of a patent applicant but also disclose it to the public. The disclosure takes place twice: at the date of the publication of the patent application and at the date of publication of the granted patent. Provided that the formal examination of required documents has been successful, the USPTO publishes a patent application "promptly after the expiration of a period of 18 months from the earliest filing date for which a benefit is sought under the title" ${ }^{107}$ The application can be published earlier, if an applicant so requests ${ }^{108}$ It must be noted that provisional applications are not published 109 The scope of the published documents generally equals to the amount of information which was provided to the USPTO during the prior stages of the patent application process ${ }^{110}$ Identical procedures are established by the EPO, the JPO, the INPI, the DPMA and the UK IPO ${ }^{111}$ Thus, the information with regard to the identity of a patent applicant is made publicly available and can be found in the registries of patent offices.

After the successful completion of both the formal and substantive examinations, the USPTO grants a patent. It grants a patent to the person who applied for the patent ${ }^{112}$, unless the patent was transferred and the patent office was notified about such transfer ${ }^{113}$ The patent owner obtains a certificate for a patent ${ }^{114}$ Afterwards, the USPTO publishes specifications and enters

\footnotetext{
105 See Rule 58 EPC Regulations, Art. 90(3)(4) EPC, Art. 90(5) EPC, Section 45(1) PatG, 18(1) DPMAV [at least one month], Section $12(3)$ UK PA.

106 See Art. 90(5) EPC; L612-12 CPI; Section 48 PatG; Section 12(3) UK PA. It must be noted that the CPI only stresses that a patent application will be abandoned when one of the requirements are not met. However, it does not specify the procedure of modification and time limit. Such a procedure is only suggested when the inventor is not designated. The time limit of correcting it is 16 months (R612-11 CPI).

107 See 35 USC 122(b)(1); 37 CFR 1.211.

108 See 35 USC $122(\mathrm{~b})(1)$.

109 See 35 USC 122(b)(2); 37 CFR 1.211(b).

110 See 37 CFR $1.215(\mathrm{a})(\mathrm{b})$.

111 See Art. 93 EPC; Rule 68 EPC Regulations; Art. 64 JPA (stresses that the name, and the domicile or residence of the applicant(s) for the patent is to be published (Art. 64(2)(i) JPA)); R612-39 CPI; L612-21(1) CPI; Section 31(2) PatG; Section 32(1)(2) PatG; Section 16 UK PA; Section 26(1) UK PRs; Section 44(1) UK PRs (in particular stresses that the name of the applicant and the address of the applicant and his address of service (Section 44(1)(a)(c) UK PRs)).

112 See 35 USC 151.

113 See 35 USC 152.

114 See 35 USC 151; 35 USC 153.
} 
the information into the register ${ }^{115}$ The USPTO procedures are not significantly different from the ones established by the EPO, the JPO, the INPI, the DPMA and the UK IPO ${ }^{116}$ In particular, the mention of the grant is published in the official patent office gazett ${ }^{117}$ and the specifications are also published soon after ${ }^{118}$ Each patent office also maintains a register, in which specific matters have to be registered and maintained ${ }^{119}$ Registers contain information about patent owners (e.g. names, addresses, nationality or residence or place of business) ${ }^{120}$ Information about representatives/agents, where applicable, is also registered ${ }^{121}$ Consequently, the public can access all necessary information concerning the initial owner of a patent.

Overall it can be concluded that the USPTO, as well as other patent offices under study, have similar legal provisions governing the identification of patent applicants. All patent offices provide patent applicants with clear requirements concerning the scope of information that needs to be provided in order to sufficiently identify an applicant. Moreover, non-compliance with those requirements leads to negative consequences, such as refusal of a patent. Such a strict remedy should presumably motivate applicants to provide the requested information to patent offices in due time. In our view, since patent offices may refuse to grant a patent unless a patent applicant sufficiently discloses her identity, it can be concluded that patent offices value this information and acknowledge its importance. In addition, patent offices timely disclose the collected information to the public, acknowledging its relevance not only for patent offices but also for third parties.

\section{The Recording of Patent Ownership Changes}

We contend that in order to establish transparency of patent ownership it is insufficient to ensure that the information concerning the original applicant and owner is efficiently collected and disclosed to the public, given that patent applications and granted patents are often subject to ownership changes that are initiated by transactions (e.g. assignments), operations of law (successions, insolvency proceedings) or court decisions. Unless the changes of applicants during the pre-grant stage or owners during the post-grant stage is notified to the patent office in

\footnotetext{
115 See 35 USC 10(a)(1); 35 USC 154; 35 USC 10(a)(1); 37 CFR 1.11(a). Access to the register is available electronically at http://patft.uspto.gov.

116 See Rule 74 EPC Regulations; Art. 97(3) EPC; Art. 98 EPC; Art. 28(1) JPA; Art. 66(3) JPA; R612-71 CPI; L612-21 CPI; R612-74 CPI; Section 58(1) PatG; Section 32 PatG; Section 24 UK PA. It has to be noted that the registration of unitary patents at the EPO is foreseen in the separate part of the European Patent Register (Rule 16 I. 3 Draft Rules 1-24 relating to unitary patent protection consolidated version 2014 (Draft Rules on UPP).

117 See Art. 97(3) EPC; L612-21 CPI; R612-74 CPI; Section 58(1) PatG; Section 32(5) PatG; Section 24(1) UK PA.

118 See Art.98 EPC; Art. 66(3) JPA; L612-21 CPI; R612-75 CPI; Section 58(1) PatG; Section 32(1) PatG; Section 32(3) PatG; Section 24(3) UK PA.

119 See Rule 143 EPC Regulations; Art. 27(1)(ii) JPA; L612-21 CPI; Section 30(1) PatG; Section 44(4) UK PRs. All patent offices provide electronic access to those registries.

120 See Rule 143(1)(c) EPC Regulations; Art. 66(3)(i) JPA; Section 30(1) PatG; Section 44(4)(b) UK PRs.

121 See Rule 143(1)(h) EPC Regulations; Section 30(1) PatG.
} 
question, the information concerning the 'current' patent owner that is available to the public will be incorrect. It is therefore important to examine whether and to what extent the patent offices under study employ mechanisms that (i) allow initial or subsequent patent applicants and/or owners to notify them about ownership changes 122 (ii) foresee effective remedies stimulating patent applicants or owners to request the recordation of the changes and (iii) monitor ownership information and transmit ownership changes to the public in a timely fashion.

\subsection{The system for recording changes of patent applicant(s) and owner(s)}

The possibility to record a change of applicant or owner is implemented in all patent offices under study ${ }^{123}$ However, the requirements concerning the recordation do vary across jurisdictions. Specifically, differences can be observed with respect to the following aspects: (i) the forms and documentation required; (ii) the parties that can file the request; (iii) the timing of recordation and (iv) the fees associated with the recordation.

\subsubsection{Forms and required documentation}

The USPTO establishes that in order to record a change of ownership the "document" has to be submitted to the patent office for recording and it has to be accompanied by a cover sheet 124 However, the exact content of the document is not specified. Presumably, the submission of an assignment agreement is intended, however, there is no straightforward obligation to submit the agreement itself ${ }^{125}$ Thus, in principle the submission may relate to any document suggesting that a transaction took place ${ }^{126}$ More specific information is provided concerning the contents

\footnotetext{
122 It must be noted that we only focus on the changes of ownership that occur during the prosecution of an application and after the grant, leaving aside issues pertaining to the assignment of rights to apply for a patent from an inventor to a third person. Moreover, we focus only on transfers of rights initiated by transactions, in particular transfers of ownership that are part of an assignment agreement, leaving aside transfers of ownership rights initiated by an operation of law or court decisions.

123 See Rule 22 EPC; Rule 85 EPC Regulations; 35 USC 261; 37 CFR 3.11(a); Art. 27(1)(i) JPA; L613-9 CPI; L613-55 CPI; Section 30(3) PatG; Section 30 UK PA; Section 32(2)(b) UK PA. See also Singer and Stauder (2003), supra 44, p. 262; USPTO MPEP, 301; Doi (2007), supra 50, p. 113; Thorley et al. (2006), supra n 50, point 10-12. The need for this mechanism is also acknowledged in the PLT. The PLT establishes that each contracting party should have a system installed allowing patent applicants or owners to record changes in the person of the applicant or owner (Rule 16 PLT Regulations). The PLT does not suggest that the recording should be obligatory; it only indicates that the recordation of the change of an applicant or owner should be possible and the necessary mechanisms should be established at patent offices.

124 See 37 CFR 3.28.

125 "The rules permit submission of true copies of assignment-related documents; original documents are not required nor desired, as they will not be returned." The word "permit" suggests that there is no obligation to submit copies of assignment-related documents. Moreover, the term "assignment-related documents" does not necessarily suggest that it has to be an assignment agreement.

126 It must be noted that if the standing of the plaintiff (or defendant, depending on the circumstances) is questioned by the opposite party during the court proceedings, based on the assumptions that the plaintiff does not own a patent,
} 
of the cover sheet. It needs to contain: (i) the name of the party conveying the interest; (ii) the name and address of the party receiving the interest; (iii) a description of the interest conveyed or transaction to be recorded; (iv) identification of the interests involved; (v) the name and address of the party to whom correspondence concerning the request to record the document should be mailed; (vi) the date the document was executed and (vii) the signature of the party submitting the document ${ }^{127}$ Thus, in principle the identity of a subsequent patent owner is sufficiently disclosed when all fields of the cover sheet are completed. For the simplification of the process of recording, the USPTO developed an online system for recording assignments the Electronic Patent Assignment System (EPAS) ${ }^{128}$ To the best of our knowledge, such a system currently only exists at the USPTO.

Similar to the cover sheet of the USPTO, the other five patent offices also advance that the request for recording has to be filed. ${ }^{129}$ To simplify the process, the INPI, the DPMA and the UK IPO provide a specific application form ${ }^{130}$ that needs to be submitted to them. These offices may also request to submit additional evidence documents, e.g. any document proving

the court will verify the rights possessed by the plaintiff. In Gaia Technologies Inc. v. Reconversion Technologies, Inc., United States Court of Appeal, Federal Circuit. August, 1996 the US Court of Appeals concluded that the appellant lacked standing based on the fact that she could not provide sufficient evidence demonstrating that she was an owner of a patent at stake. The appellant based her right on the minutes of the meeting of the shareholders. The evidence was not sufficient since "the relevant status require an assignment of patents... to be in writing". The judge based his analysis on the Arachnid Inc. v Merit Industries Inc. 939 F. 2d 1574, 19 USPQ2d 1513 (Fed.Cir.1991) where a similar problem was discussed. In Arachnid Inc. v. Merit Industries Inc. Arachnid tried to claim her rights by providing a consulting agreement as an evidence document. The court has decided that a consulting agreement, was considered not sufficient, since it "was an agreement to assign, not an assignment" and it "does not rise to the level of a present assignment of an existing invention" (at 1580, 19 USPQ2d).

127 See 37 CFR 3.31 .

128 See http://epas.uspto.gov.

129 See 22(1) EPC Regulations; http://www.jpo.go.jp/english/faqs/procedures.html\#anchor2-5; R613-55 CPI; 28 DPMAV; 47(1) UK PRs. The similarities in the format can again be partly explained by the fact that Rule 16 of the PLT harmonized the procedure for the Member States. In particular, Rule 16(1)(a) PLT indicates that a change of an applicant should be registered upon a request for recordation "signed by the applicant or owner, or by the new applicant or new owner" and a delivery to a patent office of prescribed information and documents. It also suggests information that may be provided in the request: "(i) indication to the effect that a recordation of a change in applicant or owner is requested; (ii) the number of the applications or patents concerned; (iii) the name and address of the applicant or owner; (iv) the name and address of the new applicant or new owner; (v) the date of the change in the person of the applicant or owner; (vi) the name of a state of which the new applicant or new owner is a national if he is the national of any state, the name of a state in which the new applicant or new owner has her domicile, if any, and the name of a state in which the new applicant or new owner has a real and effective industrial or commercial establishment, if any; (vii) the basis of the change requested." A patent office may request additional documents (Rule 16(2) PLT), for instance, a copy of the contract verifying the transfer of application or ownership, so called 'evidence documents'.

130 See the INPI form 'Demand d'inscription au register national d'un acte affectant la propriété ou la jouissance d'un depot'; the UK IPO Form 21; the DPMA 'Antrag auf Eintragung. It is also specified in a legal provision which exact information has to be indicated on the request. It needs to specify the file number of a patent; the name, domicile and address of the owner of a patent, information on the assignee; and in case the assignee has accorded a representative, the name and address of the representative (§28(2) (DPMAV). 
the change of ownership (for instance, an assignment agreement or a declaration signed by the parties 131 Those evidence documents are either an obligatory part of a recordation, as in case for the EPO ${ }^{132}$, the JPO and the UK IPO ${ }^{133}$ or may be requested in particular situations. For instance, the DPMA does not require to provide any evidence documents if the request is signed by both an initial patent applicant/owner and a subsequent applicant/owner or their representatives ${ }^{134}$ However, if the request is signed only by a subsequent applicant/owner, she needs to either attach a declaration signed by the registered applicant/owner or provide other evidence documents, such as an assignment agreement, proving that the assignment took place ${ }^{135}$ The evidence document needs to be signed both by an initial applicant/owner and a subsequent applicant/owner.

\subsubsection{The right to apply for the recording}

The USPTO does not explicitly specify who has the right to apply for the recording of ownership changes. It seems that any party could file a cover sheet, for instance, through the Electronic Patent Assignment System (EPAS). Based on the provided information the change of ownership will be recorded. It is even more surprising that the provided information is not verified by the

\footnotetext{
131 See Rule 22(1) EPC Regulations; R613-56 CPI; §28(3)(2) DPMAV; Section 47(2) UK PRs. The EPO, for instance, specifies that "registrations of transfers (assignments) of European patent applications are recorded in the European Patent Register at the request of an interested party and on production of documents satisfying the EPO that the transfer has taken place. This might be a copy of or extract from an official document, or a declaration signed by both parties" (http://www.epo.org/service-support/faq/own-file.html\#faq-287). Thus, evidence documents do not have to be original assignment agreements. The JPO, however, seem to prescribe that "the original assignment document" has to be sent to the patent office. Instead of the original assignment document, you can submit a notarized copy of the document that has been certified by a notary public. A notarized copy of the document certified by a notary public is also admissible. http://www.jpo.go.jp/english/faqs/procedures.html\#anchor2-5

132 The EPO suggests that an interested party needs to provide "clear-cut evidence of a transfer" (Decision of the Legal Board of Appeal of 13 October 1998 (EPO J 26/95), point 2). In particular, the documents which "only created the obligation to assign rights" are not admissible since they "did not constitute the assignment itself" (Decision of Technical Board of Appeal 3.3 .02 of 26 April 2012 (EPO T 1751/07), point 2). For example, in the Decision of the Legal Board of Appeal 3.1.1 of 24 January 2002 (EPO J 0012/00), it has been decided that the provided Employee Confidentiality and Inventions Agreement and the Proprietary Information and Inventions Agreement were not since "they both not equivalent to an assignment agreement" (point 7) and "they did not show clearly that an assignment of the co-applicant's right to the European Patent Application... had really been carried out" (point V). The EPO Legal Board of Appeal has also established that it is sufficient to provide extracts from the assignment agreements as evidence and not a full agreement: "the submission of extracts in the form of the pages concerning the transfer of rights is not unusual and is commonly attributable to the fact that, in the interests of the parties, not all details of such an agreement, which may be broader in scope, should be disclosed" (Decision of the Legal Board of Appeal 3.1.01 of 15 June 2015 (EPO J 0016-14), point 2.2.2).

133 See Rule 22(1) EPC Regulations; Rule 47 UK PRs; http://www.jpo.go.jp/english/faqs/procedures.htm

134 See § 28(3) DPMAV.

135 See § 28(3) DPMAV.
} 
USPTO which is explicitly mentioned on the EPAS web page ${ }^{136}$ In our view such a practice can lead to inconsistences and incorrect recordings, considering that a person applying for the recording may not be obliged to provide any evidence documents.

The EPO allows 'any interested party' to request a recording ${ }^{137}$ However, in comparison to the USPTO, the EPO does oblige such a party to provide evidence documents with every application, such as a copy of an assignment agreement or a declaration signed by both parties. The other patent offices seem to be less flexible and specify that the recordation has to be requested at least by one of the parties to an assignment (or on their behalf) ${ }^{138}$ For instance, the JPO foresees two scenarios: (i) either both a registered holder (registered applicant/owner) and a successor (subsequent applicant/owner) apply together for registration of an assignment or (ii) a successor can request the recordation with the written consent of the right holder ${ }^{139} \mathrm{~A}$ similar logic is applied by the DPMA: if the request is submitted only by the successor, evidence of the assignment has to be submitted 140

\subsubsection{The timing of recording}

The USPTO advises to record a change of ownership within three months from the date of an assignment to avoid potential negative consequences for the subsequent applicant/owner ${ }^{141}$ However, in general, the change of an applicant or an owner can be registered at any time during the lifecycle of a patent. A transfer is generally only acknowledged from the date when the office receives all the required documents and the fees are paid ${ }^{142}$ A noteworthy observation in the European contexts is that a change of an owner of a European patent can only be recorded by the EPO during the opposition period or during opposition proceedings: ${ }^{143}$ The registration of transfers made afterwards fall within the responsibility of national patent offices. ${ }^{144}$ It must be noted that, overall, the Rule 22 of the EPC Regulations governs both a change of ownership in European patents and unitary patents and the procedure of recording a change of ownership

\footnotetext{
136 See https://epas.uspto.gov : "Assignment information provided by the user will be recorded as provided and will not be verified or modified by the USPTO."

137 See Rule 22 EPC Regulations.

138 See http://www.jpo.go.jp/english/faqs/procedures.html\#anchor2-5; R613-55CPI; 28(3) DPMAV; 32.09 Manual of Patent Practice.

139 See http://www.jpo.go.jp/english/faqs/procedures.html\#anchor2-5.

140 See 28(3) DPMAV.

141 See 35 USC 261.

142 See for instance the Decision of the Technical Board of Appeal 3.4.01 of December 2010 (EPO T 0128/10): "According to Rule $22 \mathrm{EPC}$ in conjunction with Rule $85 \mathrm{EPC}$, the procedural requirements to be fulfilled for recording the transfer of a European patent in the European Patent Register consist in the filing of a request of the interested party, the production of documents providing evidence of the transfer, and the payment of an administration fee. These requirements do not need to be fulfilled at the same time. If they are met on different dates, the transfer shall only have effect vis-à-vis the EPO at the date on which all the requirements mentioned above are fulfilled", point 3.5.

143 See Rule 85 EPC Regulations.

144 See IX., National law relating to the EPC.
} 
does not differ. However, when it comes to the timing of recordation, it can be presumed that the EPO will record a change of an owner of a unitary patent throughout the life of a patent since the EPO is under obligation to administer the Register for unitary patent protection. 145 Moreover, the unitary patent could only be transferred for all participating Member States simultaneously ${ }^{146}$ which, in comparison to the current European patent, significantly simplifies the search of the actual owner since owners of unitary patents cannot differ depending on the territory.

\subsubsection{Fees}

Only the USPTO and the DPMA do not impose the payment of any fees in order to record a change of applicant/owner ${ }^{147}$ However, recordation with the USPTO is only free of charge when the request is submitted through an online assignment system. If the request is not submitted electronically the fee amounts to 40 dollars ${ }^{148}$ The EPO requires the payment of 100 euros ${ }^{149}$ the INPI requires 26 euros per recording but limits the maximal payment to 260 euros if multiple recordings are requested 150 the UK IPO requires 50 pounds 151 , the JPO requires 4,200 yen (around 30 euros) for a change of an applicant and 15,000 yen (around 120 euros) for a change of an owner ${ }^{152}$.

Overall, the fees for recording a single change of ownership with most patent offices are relatively low. However, considering that entire bundles of patents can change ownership at the same time and that patent protection is territorial in nature the fees can add up to significant amounts quickly. Especially when an ownership change relates to inventions for which patent protection is sought in multiple jurisdictions, the fees associated with the recording of ownership changes might discourage parties to record such changes of ownership. In the European context, this problem is partially mitigated by the unitary patent since a change of ownership is recorded for all participating Member States simultaneously ${ }^{153}$ Thus, in comparison to the European patent, the fee to record an ownership change is considerably lower.

\footnotetext{
145 See Art. 9(1)(b) UPR.

146 See Art. 3(2) UPR.

147 See 37 CFR 3.41; Information of Costs, Fees and Expenses (A9510.1) of the German Patent and Trade Mark Office and of the Federal Patent Court 2014 do not specify any fees.

148 See 37 CFR 3.41.

149 See Fee code 022 http://www.epoline.org/portal/portal/default/epoline.Scheduleoffees.

150 See Tableau annexe: redevances de procédure, Section 6, Arrêté du 24 avril 2008 relatif aux redevances de procédures perçues par l'Institut national de la propriété industrielle.

151 See Rule 6 Schedule 1 PRs.

152 See https://www.jpo.go.jp/tetuzuki_e/ryoukin_e/ryokine.htm.

153 See Art. 3(2) UPR.
} 


\subsection{The failure to record changes of applicant(s) and owner(s)}

The USPTO specifies that a non-recorded assignment may be void "against any subsequent purchaser or mortgagee... unless it is recorded in the USPTO within three months from its date or prior to the date of such subsequent purchase or mortgage" ${ }^{154}$ This means that a subsequent transaction will prevail over the previous and the former will lose the rights to the patent. Nevertheless, the remedy may not be effective when the assignment of rights is initiated by an operation of law (succession, insolvency), since the registered patent owner seized to exist and there is no risk that a patent will be subsequently assigned. On the other hand, according to the EPO the rules regulating the recording of the change of ownership are not applicable in the context of universal succession in law (e.g. inheritance and merger) ${ }^{155}$ Thus, the universal succession may in general be treated as an exceptional case and may not be a good example to question effectiveness of established remedies. The effectiveness of the remedy established by the USPTO can also be questioned when there is a close relationship between an assignee and the assignor and/or a high level of trust is established between the two. Under these circumstances it is unlikely that any subsequent purchase will occur and, therefore, a non-registered subsequent owner will not bear any negative consequences of not recording the change of ownership. Since in the USC a remedy of non-enforceability is not foreseen, it can be assumed that the nonrecordation of a change of ownership cannot prevent the subsequent owner from defending her rights in court ${ }^{156}$ However, the opposite party can in principle question the ownership status that will be subsequently verified by the court 157

\footnotetext{
154 See 35 USC 261. See also AIPPI US Q190 'Contracts regarding Intellectual Property Rights (assignments and licenses) and third parties', p. 2.

155 See Decision of Technical Board of Appeal 3.3.04 of 17 June 2004 (T 15/01), point 11. In this case, the Technical Board of Appeal concluded that "when an applicant or patentee ceases to exist, his universal successor in law [in this case the subject was a merger] immediately and automatically acquires the party status in proceedings pending before the EPO". On the contrary, if a subsequent patent owner obtains rights, for instance, through an assignment agreement, the EPO established that she lacks standing unless the change of ownership was recorded before the proceedings (see more explanation below and footnote...). In addition, the EPO established that the "change of name does not alter the identity of the legal person" (Decision of the Legal Board of Appeal 3.1.01 of 27 July 2006 (EPO J 0016/05 3.1.01), p. $12)$.

156 See In Gaia Technologies Inc. v. Reconversion Technologies, Inc., United States Court of Appeal, Federal Circuit. August, 1996 it is stated that "the recording of an assignment is necessary only to protect the assignee from subsequent bona fide purchasers without notice".

157 See In Gaia Technologies Inc. v. Reconversion Technologies, Inc., United States Court of Appeal, Federal Circuit. August, 1996, the appellant could not prove she was the owner of a patent, since she could not provide sufficient evidence documents and, thus, lacked standing. However, if the appellant proved she was a legitimate owner of a patent by providing sufficient evidence (an assignment agreement), she would be allowed to defend her rights in court and the proceedings would continue. "If Gaia can prove that it was the assignee of the Intellectual Property at the time the suit was filed, Gaia has standing to sue for the patent infringement under 25 USC 281 (1994) as a patentee". It must be noted, however, that in this case the change of ownership was recorded by the UPSTO, though without obtaining and verifying any evidence documents. A case where the non-recording of a change of ownership prior to initiating court proceeding amounted to lack of standing was not found most probably due to the fact that, as it was mentioned
} 
A 'USPTO-type remedy' is also established by the UK IPO ${ }^{158}$ which in addition indicates that if the recording is not done within six months from the transaction, the court or comptroller shall not award the actual owner costs or expenses ${ }^{159}$ The INPI and DPMA induce a broader effect of non-recording a change of applicant or owner: non-enforceability of patent rights against third parties until the recording is made $\sqrt{160}$ This effectively means that the registered owner remains subject to rights and obligations, including the enforceability of patent rights, until the change of ownership is recorded. As aforementioned, most patent offices do not impose a strict time limit for the recordation and subsequent patent owners may potentially record the change at any time, for instance, prior to initiating a lawsuit. Despite the fact that the EPC does not specify any remedy for the non-recording of a change of applicant or owner, the EPO case law reveals that the patent office follows the similar logic as the INPI and DPMA. In particular, the non-recorded subsequent patent owner cannot defend its rights during proceedings at the $\mathrm{EPO}$ and the registered owner will be considered to be the legitimate party ${ }^{161}$ Moreover, the recordation of a change of ownership needs to be completed before the expiry of the period for filing the notice of appeal if the subsequent owner decides to appeal the decisions of the Receiving Section, Examining Divisions, Opposition Divisions or the Legal Division; otherwise the appeal filed by the non-recorded subsequent owner will be inadmissible ${ }^{162}$ With regard to the unitary patent, it can be assumed that the subsequent owner would also need to record her rights to be viewed as a legitimate party to the proceeding before the EPO or the Unified Patent Court(UPC).

above, the USC does not connect the enforceability of patent rights and the need to record change of ownership. The proof of rights, when questioned during the court proceedings, is sufficient to have standing.

158 See Section 33(1) UK PA. See also AIPPI UK Q190 'Contracts regarding Intellectual Property Rights (assignments and licenses) and third parties', p. 1.

159 See Section 68 UK PA. See also AIPPI UK Q190, p. 1; Thorley et. al. (2006), supra n 50, point 10-21.

160 See Section 30(3) PatG; R613-55 CPI. See also AIPPI Germany Q190 Contracts regarding Intellectual Property Rights (assignments and licenses) and third parties, p. 4; AIPPI France Q190 Contracts regarding Intellectual Property Rights (assignments and licenses) and third parties, p. 2.

161 See Decision of the Enlarged Board of Appeal of 25 May 2005 (EPO G 0002/04): The procedural status of the proprietor cannot be transferred without the substantive title; Interlocutory Decision of the Technical Board of Appeal 3.3.03 of 24 November 2005 (EPO T 0261/03): "A first condition to be met is that the competent organ of the EPO before which the opposition proceedings are pending be informed about the transfer of the relevant business. It follows from the established case law of the EPO that without such a notification the transferor of the business remains opponent and the transferee does not acquire opponent status", point 3.2.; Decision of the Technical Board of Appeal 3.4.01 of 10 December 2010 (EPO T 0128/10-3.4.01), point 2.2; Decision of the Technical Board of Appeal 3.4.01 of 1 December 2011 (EPO T 0960/08.4.01): The boards of appeal have consistently held that formal requirements have to be fulfilled for the opponent status to be considered transferred, point 2.2.

162 In particular, it is stated that for a transferee of a patent to be entitled to appeal, the necessary documents establishing the transfer, the transfer application and the transfer fee pursuant the Rule 20 EPC [currently Rule 22 EPC] must be filed before the expiry of the period for appeal under Article 108 EPC [within 2 months]. Later recordal of the transfer does not retroactively validate the appeal (Decision of the Technical Board of Appeal 3.3.4 of 18 May 2001 (EPO T 656/98), headnote; see also Decision of the Technical Board of Appeal 3.4.01 of 10 December 2010 (EPO T 0128/10 3.4.01), point 3.8). 
The stronger enforcement mechanism is arguably established by the JPO. The JPO goes beyond the non-enforceability against third parties effect and provides that an assignment needs to be recorded with the patent office for it to take effect between the contracting parties (succession in law excluded) ${ }^{163}$ However, the JPO does not specify the time limit for such recordation. In any case, if in practice the contractual obligation between contracting parties does not take effect unless it is recorded, a subsequent patent owner may be more motivated to record an assignment to ensure that the transaction is legitimate. In other patent office under study the legitimacy of the contractual transaction is not directly conditioned on the registration of the change of ownership. However, it is unclear whether this stronger remedy is strictly enforced. If the parties may register the transaction at any moment (e.g. prior to initiating a lawsuit) without any negative consequences, this remedy in practice would not be stronger than the one established by the USPTO. The only risk a subsequent patent owner undertakes is that the registered owner may assign the patent to another party in the meantime and the previous transaction would not be valid since it was unregistered.

Overall, it can be concluded that the potential repercussions for not recording a change of applicant or owner are generally not very strict, especially not when it comes to the EPO, the INPI and the DPMA where no time limits for the recordation are imposed and the repercussions of non-enforceability can be easily avoided. Similarly, the "subsequent purchaser" remedy may not be effective, for instance, when there is a low level of risk that the registered owner will reassign a patent (e.g. when there is high level of trust between the parties). Given that the repercussions are not severe, parties may not be motivated to record a change of ownership when it is executed but only record it when it is absolutely necessary, for instance, in order to enforce a patent. Moreover, in case of USPTO and UK IPO patents, the right to enforce a patent by the subsequent owner does not depend on the prior recordation. The subsequent owner of a UK IPO patent in case of non-recording within six months from the assignment, however, risks losing costs and expenses awarded during the litigation. In our view, this potential financial disadvantage may incentivize a subsequent owner to record a change of ownership.

\subsection{The disclosure of changes of ownership to the public}

Another important aspect to consider is whether patent offices transmit the acquired information related to the change of ownership to the public. As aforementioned, all patent offices under study maintain a register of interests in patents ${ }^{164}$ The changes of ownership are entered to the registries of all patent offices under study. The UK IPO specifies that the change "must be entered in the register as soon as practicable after it occurs (or, if later, when the application

\footnotetext{
163 See Art. 34(4) JPA; Art. 98 JPA; AIPPI Japan Q190 Contracts regarding Intellectual Property Rights (assignments and licenses) and third parties, p. 1; Doi (2007), supra n 50, p. 120.

164 See 35 USC 261; Rule 143(w) EPC Regulations; 27(1)(i) JPA; R613-53 CPI; 30(3) PatG; 44(6) UK IPRs.
} 
is published). 165 No other patent office provides any reference to the timing of entrance of the collected information to the registry.

It can be concluded that, on the positive side, all patent offices under study installed a system allowing initial patent owners and/or their successors to record a change of ownership. However, the system has a lot of limitations. The major drawback, in our view, is that there is frequently no time pressure to register the change of ownership which indirectly allows the parties to do it when it is absolutely necessary. Moreover, not every patent office imposes a party requesting a change of ownership to be recorded to provide evidence documents, which may lead to errors ${ }^{166}$ In addition, there is a risk that some patent offices accept low quality evidence documents, such as employment agreements instead of assignment agreements, which constitute an obligation to assign the rights but do not prove that an assignment took place 167

Overall the procedure of requesting a recording seems to be relatively easy: parties need to submit a request, in some cases evidence documents, and pay fees. This narrow scope of the requirements, in our view, is not demanding and can be complied with. This view is also supported by the EPO which claims that "the procedure is particular simple and easy to comply with", "merely because the requirement is so simple to comply with, is no reason to ignore it" 168 Unfortunately, the simplicity of the process clearly does not encourage patent owners to record the change of ownership. On the contrary, it is perceived as an extra administration burden (especially when the recording needs to be done in multiple patent offices) and a waste of financial resources. The potential need to translate relevant documents into national languages may also complicate the procedure and increase associated costs. The engagement into incurring extra expenses is only justifiable for some owners when there is a clear need to be identified, such as enforcement of patent rights in case of the EPO, INPI and DPMA patents. Not to mention that some owners strategically decide not to disclose their identity. This so-called "voluntarily" recordation of change of ownership significantly downgrades the quality of registries maintained by patent offices. A third party cannot be certain that the registered owner is an actual owner and would be forced to search for other means of obtaining this important piece of information. 


\section{Legislative Initiatives to Improve the Transparency of Patent Ownership}

In response to executive actions announced by the White House on June $4^{\text {th }}, 2013$ to "help bring about greater transparency to the patent system and level the playing field for innovators", the USPTO published a Notice on "Proposed Changes to Require Identification of Attributable Owner" on February $20^{\text {th }}, 2014$. To the best of our knowledge, this notice represents the only attempt directly aimed at making patent ownership information more readily available to the public that has been initiated in the jurisdictions that we study. Despite the fact that the EPO and the European Commission also acknowledge flaws in the recordation of patent ownership changes 169 , the USPTO Notice is not met by equivalent initiatives, including the on-going the Unitary Patent Package (UPP) initiative. The USPTO Notice proposes several modifications to 37 CFR Part 1 that relate to (i) which information needs to be provided to the USPTO when filing a notice, (ii) the occasions in which a notice that identifies a current owner needs to be provided and (iii) the consequences of non-compliance with the suggested rules.

\subsection{The identification of the attributable owner(s)}

\subsubsection{The notion of attributable owner}

With the notion of 'attributable owner' the USPTO refers to two types of entities: (a) titleholders and (b) enforcement entities ${ }^{170}$ The titleholder is an entity that "exclusively or jointly has been assigned title to the patent or patent application" ${ }^{171}$ The enforcement entity is an entity that is "necessary to be joined in a lawsuit in order to have standing to enforce the patent or any patent resulting from that application" ${ }^{172}$ Information about these types of entities is currently not collected by the USPTO. However, since those entities are "real-parties-in-interest", having the right to enforce a patent 173 , their identity should ideally also be publicly disclosed alongside the identity of titleholders.

Moreover, the Notice foresees the possibility that the actions of a titleholder or an enforcement entity may be controlled by another entity. For this reason attributable owner(s) would also need to provide information about the identity of the 'ultimate parent entity' ${ }^{174}$ An ultimate parent entity is defined as "an entity which is not controlled by any other entity" 175 To have the complete picture of 'who-owns-what' the USPTO would ideally obtain information

\footnotetext{
169 See Report of the Expert Group on patent aggregation, p. 57.

170 See Federal Register 2014 79(16), p. 4109.

171 See 37 CFR $1.271(\mathrm{a})(1)$.

172 See 37 CFR 1.271(a)(2).

173 See Federal Register 2014 79(16), p. 4107.

174 See 37 CFR 1.247(b), Federal Register 2014 79(16), p. 4110.

175 See 16 CFR 801.1(a)(3).
} 
with regard to so-called 'hidden beneficial owners ${ }^{176}$, referring to entities that are attempting to hide their identity by "temporarily divesting themselves of ownership rights through contractual or other arrangements" ${ }^{177}$ The Notice further specifies what is understood by the term 'entity'. Primarily it can be "a natural person, corporation, company, partnership, joint venture, association, joint-stock company, trust, estate of a deceased natural person, foundation, fund, or institution, whether incorporated or not, wherever located and of whatever citizenship" 178

\subsubsection{The requirements for identifying the attributable owner(s)}

In 37 CFR 1.271 (f) the Notice specifies that an entity needs to provide to the USPTO in order to sufficiently identify the attributable owner. Different levels of information are required depending on the type of entity in question. A natural person is obliged to provide "the full legal name, residence and a correspondence" $[79$ If an attributable owner is a public company, its name, "stock symbol, and stock exchange where the company is listed" must be specified ${ }^{180}$ To identify a non-public company, its name, "place of incorporation, and address of the principle place of business" must be provided ${ }^{181}$ The identification of a partnership must include "the name of the partnership and address of the principle place of business" 182 With regard to any other entity the following information must be submitted: "its name, if organized under the laws of state, the name of the state or legal form of organization, and address of the principle place of business" 183

\subsection{Occasions for submitting information concerning the identity of the attributable owner(s)}

There are in total six occasions listed in the Notice at which a patent applicant or owner is requested to provide information about the current attributable owner(s). Those six occasions can be grouped into two categories: (1) the identification of the attributable owner(s) in pend-

\footnotetext{
176 See Federal Register 2014 79(16), p. 4110. In 37 CFR 1.271(c) the hidden beneficial owner is defined as "any entity that, directly or indirectly, creates or uses a trust, proxy, power of attorney, pooling agreement, or any other contract, arrangement, or device with the purpose or effect of temporarily divesting such entity of attributable ownership of a patent or application, or preventing the vesting of such attributable ownership of a patent of application".

177 See Federal Register 2014 79(16), p. 4110.

178 See 37 CFR 1.271(d)(1). For more details on the term 'entity' see 37 CFR 1.271(d)(2)(3)(4). Additionally, in 37 CFR 1.271(e) the proposal specifies that the term 'entity' "does not include any foreign state, foreign government, or agency thereof (other than a corporation or unincorporated entity engaged in commerce), and also does not include the United States, any of the States thereof, or any political subdivision or agency of either (other than a corporation or unincorporated entity engage in commerce).

179 See 37 CFR $1.271(\mathrm{f})(4)$.

180 See 37 CFR 1.271(f)(1).

181 See 37 CFR 1.271(f)(1).

182 See 37 CFR 1.271(f)(3).

183 See 37 CFR 1.271(f)(5).
} 
ing applications and (2) the identification of the attributable owner(s) in patents involved in proceedings before the office.

\subsubsection{The identification of the attributable owner(s) in pending applications}

The first category includes three occasions at which the attributable owner needs to be identified: (i) during the filing stage of a patent application, (ii) in case of an ownership change during the patent prosecution stage and (iii) at the receipt of the notice of allowance. First, the attributable owner needs to be the first to be identified of all identified parties during the filing of a patent application, a reissue application and "each international application that commenced the national stage under 35 USC 371(b) or (f)" ${ }^{184}$ It must be noted that the provision is only applicable to nonprovisional patent applications under 35 USC 111(a). The requirements do not apply to either provisional patent applications or international applications prior to the commencement of the national stage (35 USC 371(b) or (f)) ${ }^{185}$

Second, in case the attributable owner has changed during the prosecution of a nonprovisional application or during the pendency of an international application under 37 CFR 1.495(b), the Notice proposes to oblige a patent applicant to file a notice that identifies current attributable owner(s) within the three month period from the date of the chang $\sqrt{186}$, whereby the three-month period cannot be extended ${ }^{187}$ Again, these requirements do not apply to provisional patent applications or international applications prior to the commencement of the national stage (35 USC 371(b) or (f)) ${ }^{188}$

Third, the USPTO suggests that once a patent applicant receives the notice of allowance ${ }^{189}$ the applicant needs to file a notice that identifies the current attributable owner(s) to the office. This document must be sent within three months from the date that the notice of allowance has been sent ${ }^{190}$ As in the previous case, this time limit cannot be extended ${ }^{191}$ If there has been no change, the patent applicant is still obliged to send a notice and indicate that there has been no change of attributable owner(s) 192

It should be noted that the failure to comply with identification requirements are dealt with differently depending on the occasion. If a nonprovisional patent application has been accorded a filing date but the patent applicant failed to identify the attributable owner ${ }^{193}$, the patent

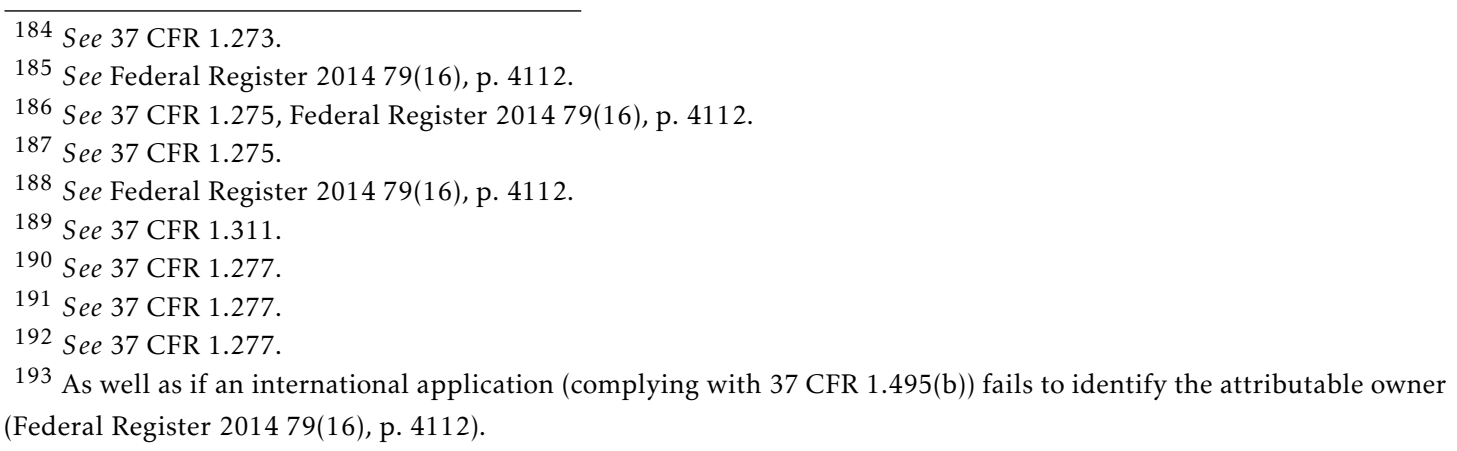


applicant will be notified about the failure and given a specified period of time to correct the deficiency ${ }^{194}$ In the Notice it is explained that the information needs to be sent within the period of two months which can potentially be extended up to eight months ${ }^{195}$ However, if the applicant fails to send the required document within this time frame, the patent application will be abandoned ${ }^{196}$ The patent application may result in abandonment also in case of failure to confirm that the recorded attributable owner information is accurate within a three-month period form the date of sending the notice of allowance 197

\subsubsection{The identification of the attributable owner(s) involved in proceedings before the office}

The second category also comprises three proposed occasions at which a patent owner is required to identify the current attributable owner(s): (i) the payment of maintenance fees, (ii) the initiation of patent trial and appeal board trial proceedings and (iii) the engagement in supplementary examination or re-examination proceedings. First, a notice needs to be sent prior to each payment of maintenance fees within the time period specified in 37 CFR $1.362(\mathrm{~d})(\mathrm{e}){ }^{198}$ It should be noted that the period for payment is rather broadly defined, e.g. 3 to $3^{1} / 2$ years after grant for the first maintenance fee, 7 to $7^{1} / 2$ years after grant for the second maintenance fee, and 11 to $11^{1} / 2$ years after grant for the third maintenance fee ${ }^{199}$ Thus, an owner of a patent is required to file a notice of attributable ownership after every four year window up until the last maintenance payment. A notice also needs to be send if no change of attributable ownership has taken place ${ }^{200}$

Second, the Notice suggests to require a patent owner to identify the attributable owner when any Patent Trial and Appeal Board Trial Proceedings is initiated for a patent at stake. In such cases the notice identifying the current attributable owner needs to be submitted simultaneously with a mandatory notice required by 37 CFR 42.8(a)(??) ${ }^{201}$ Moreover, if the attributable owner has changed during the trial proceedings, an additional notice needs to be submitted by the patent owner within 21 days from the date of the change of attributable owner 202

Third, the USPTO aims to oblige patent owners to accompany a request for supplementary examination (37 CFR 1.610), a request for ex parte reexamination (37 CFR 1.510) and a reply or any other paper filed by the patent office in an ex parte reexamination proceeding by a notice

\footnotetext{
194 See 37 CFR 1.273, Federal Register 2014 79(16), p. 4112.

195 See Federal Register 2014 79(16), p. 4112.

196 See 37 CFR 1.273.

197 See 37 CFR 1.277, Federal Register 2014 79(16), p. 4112.

198 See 37 CFR 1.381.

199 See 37 CFR $1.362(\mathrm{~d})$

200 See 37 CFR 1.381 .

201 See 37 CFR 1.383.

202 See 37 CFR 1.383.
} 
identifying the current attributable owner ${ }^{203}$ If the attributable owner changed during the reexamination proceedings, the notice needs to be filed within three months from the date of the change 204

Despite the fact that the notice does not specify any punitive action in case of a failure to notify the attributable owner in the three described occasions, it is indicated that a failure to notify the USPTO by error "may be excused on petition accompanied by a showing of reason for the delay, error, or incompleteness and the petition fee" 205

\section{Recommendations for Improving the Transparency of Patent Ownership Changes}

Although the USPTO has ultimately opted not to advance the Notice on "Proposed Changes to Require Identification of Attributable Owner", the provisions proposed by the notice and the comments submitted by stakeholders during public hearings thereupon provide a suitable starting point for a discussion of the 'minimal requirements' that future initiatives aiming to improve the transparency of patent ownership need to take into account. We present an overview of the comments submitted by public firms in Table 1 below ${ }^{206}$ In what follows we group these requirements together into four categories; (i) requirements concerning the scope of ownership to be disclosed (the 'who-question'), (ii) requirements concerning the timing of the disclosure of ownership information (the 'when-question'), (iii) the type and extent of corrective action upon failure to meet requirements concerning the disclosure of ownership information (the 'what-if-question') and (iv) requirements concerning the recording and public disclosure of submitted ownership information (the 'how-question'). Our recommendations are based on the belief that the transparency of patent ownership is an essential part of patent notice and that patent notice is key to the functioning of markets for technology. The principle of transparency is one of the key principles of property law and can be divided into "passive transparency" and "active transparency" ${ }^{207}$ Whereas the objective of passive transparency is to ensure that certain information is available and accessible the objective of active transparency is to ensure that information is not only available but also complete and useful. One of the means to achieve

\footnotetext{
203 See 37 CFR 1.385.

204 See 37 CFR 1.385 (c).

205 See 37 CFR 1.387

${ }^{206}$ The submitted comments on the proposed changes to require identification of attributable owner(s) were previously accessible at https://www.uspto.gov/patent/laws-and-regulations/comments- public/comments-changesrequire-identification-attributable. We accessed and downloaded all documents containing submitted comments on March $10^{\text {th }}, 2015$. All documents are available upon request.

207 See e.g. Peter Drahos, The Global Governance of Knowledge: Patent Offices and Their Clients (2010). See also Thomas Cottier and Michelangelo Temmerman, Transparency and IP Protection in International Law, in Bianchi, A. and Peters, A. (eds.) Transparency in International Law, (2013).
} 
both passive and active transparency of property is to establish and maintain property registers. Hereby, one can distinguish between property registers that rely on the "voluntary" registration of ownership and those that rely on the "obligatory" registration of ownership 208 Whereas the former registry system is based on 'positive enforcement' by providing property owners that register properties with certain privileges, the latter is based on 'negative enforcement' by inducing 'penalties' for not registering properties. In our comparative analysis of requirements for the establishment of patent owners we have essentially argued that whilst the registration of patent ownership changes is obligatory de jure, it is voluntary de facto in most jurisdictions under study. We argue that an active transparency of ownership can only be achieved if the registration of patent ownership changes shifts from a voluntary registry system towards a more obligatory one.

\subsection{Requirements concerning the scope of ownership to be disclosed}

We propose that the requirement to disclose information about the identity of the applicant/owner of a patent (application) should be confined to the name(s) and registered address of the exclusive or joint title holder(s) and her/their ultimate parent entity. Whilst the inclusion of a broad set of enforcement entities, defined as "any entity necessary to be joined in a lawsuit in order to have standing to enforce that patent or any patent resulting from the application" in the USPTO notice, may certainly limit the activities of entities that purposely seek to benefit from hiding their ownership, we contend that the disclosure of ownership of the title holder(s) and ultimate parent entity is sufficient to allow for an efficient functioning of markets for technology 209 Furthermore, we believe that limiting the requirement for the disclosure of ownership information to these entity types strikes a fair balance between ensuring a consistent flow of information to the public and the potential of imposing unduly burdensome requirements that may negatively impact the legitimate confidentiality of business interests ${ }^{210}$ We contend that the disclosure of information on the identity of the title holder(s) and her/their parent entity is part of the quid pro quo through which inventors are granted exclusive rights to their invention and is readily available to parties required to submit this information to patent offices.

\subsection{Requirements concerning the timing of the disclosure of ownership in- formation}

We propose that given that technology transactions can occur throughout the entire lifetime of patents, any future initiative should impose requirements to record changes of ownership regardless of when they occur during the patent lifecycle, within a reasonable time window

\footnotetext{
208 See e.g. Alison Clarke and Paul Kohler, Property Law (2005).

209 See e.g. the comments submitted by the Cook Group and GlaxoSmithKline in Table 3.1.

210 See e.g. the comments submitted by GlaxoSmithKline and Novartis AG. in Table 3.1.
} 
Table 1: Submitted comments of firms to the USPTO Notice (part 1).

\begin{tabular}{ll}
\hline \multicolumn{1}{c}{ Appraisal/Criticism } & \multicolumn{1}{c}{ Proposed Modifications } \\
(Manufacture of medical and dental instruments and supplies)
\end{tabular}

Dell Inc. \& Cisco Systems

(Manufacture of computers and communication equipment)

- The PTO's proposed rules will promote the notice function of patents and innovation. The PTO's proposed attributable ownership requirement will not only enhance the PTO's ability to carry out its operations but also will promote innovation by providing accurate information to the public.

- Dell Inc. \& Cisco Systems contend that the PTO's efforts to improve patent transparency will help all firms, large and small.

- The "who" question: Attributable owners for reporting purposes should be clarified to include a broader class of enforcement entities and should include entities that seek to hide their attributable ownership for more than a temporary period.

- The "when" question: Attributable ownership by a patent assertion entity should be promptly recorded.

- Confidential treatment of attributable ownership respecting patent applications should be limited to owners-not including patent assertion entities-who can assert a commercial justification for confidentiality.

\section{GlaxoSmithKline}

(Manufacture of pharmaceutical preparations)

- The burden estimate provided in the notice does not meet legal and regulatory requirements.

- The office has not specifically identified why voluntarily recording assignments is not adequate.

- It is unclear what is meant by "an entity necessary to be joined in a lawsuit in order to have standing to enforce the patent or any patent resulting from the application".

- The attributable owner should be limited to the titleholder as set forth in a recorded assignment.
- In view of the shortcomings of the burden estimate provided in the Notice, GSK requests the Office to reissue the Notice of proposed rulemaking with a burden estimate that meets all of the legal and regulatory requirements and to reset the 60-day period for comment. 
Table 1: Submitted comments of firms to the USPTO Notice (part 2).

- Times for identifying attributable owner should be limited to filing and, issuance, and start of post grant proceedings.

- GSK believes that the titleholder can be identified on the application data sheet.

- GSK believes it is adequate to identify the name of the legal entity and the registered place of business (e.g., city and state of incorporation).

- The penalty for non-compliance is unclear in some instances.

\section{Hewlett-Packard Company \\ (Manufacture of computers and peripheral equipment)}

- HP supports the disclosure of attributable owner information at key checkpoints during the lifecycle of a patent.

- The Submission of attributable owner information would provide important benefits;

- The effectiveness of the proposed rules in the Notice will turn on the precision of the definition of "attributable owner". The Notice defines several types of entities that are included within the scope of the term "attributable owner".

- The rules requiring the submission of attributable owner information should be designed to minimize the burdens for submitting the information, while maximizing the accuracy of the information. Requiring a submission or confirmation of attributable owner information at key checkpoints during the life of a patent, as generally proposed in the Notice, would attain a reasonable balance between these competing considerations.

Response to arguments against reporting attributable owner information;

- Burdens of providing the information; in the majority of cases, disclosing the attributable owner information to the USPTO would simply be a matter of providing information that is already known or readily determined at a time when the party is already interacting with the USPTO. That being said, HP believes that the impact on entities with large portfolios will be proportionately greater than for small entities.

- Proper tailoring of the proposed rules; HP believes that the problem goes well beyond the situations of demand letters and litigation, and as a result, the proposal will only fully capture the intended benefits if the USPTO requires attributable owner information for applications and patents, regardless of whether they are the subject of a demand letter or litigation. 
Table 1: Submitted comments of firms to the USPTO Notice (part 3).

\begin{abstract}
- Improved ownership information will enhance the Office's ability to properly examine pending applications and to review issued patents; benefit the public in managing business affairs increasingly influenced by IP rights, and help fulfill the public notice function of the patent system by enabling members of the public to determine what areas of endeavor are covered by unlicensed patents and patent portfolios and what areas are not. The requirement to properly identify a patent owner also balances the existing requirement for challenges in inter partes patent proceedings to identify all their real parties in interest, thus levelling the playing field for challengers struggling to determine which patents warrant attention.
\end{abstract}

IBM Corporation

(Computer programming activities)
- IBM believes that changes must be made to the scope of the definition of "attributable owner" to collect useful information without hampering patenting and licensing. IBM supports identification of the exclusive or joint titleholder, opposes identification of entities necessary to be joined for standing to sue, supports identification of the ultimate parent entity in a way that does not burden applicants and owners, and opposes the requirements in subsection (d) regarding entities used to divest or prevent the vesting of title.

- IBM believes it is reasonable to require disclosure of attributable owner information at filing, issuance, payment of maintenance fees, and at appropriate times during ex parte and inter partes post issuance proceedings. IBM is concerned, however, that the specific timing requirements proposed by the Office for updating attributable owner information during prosecution are overly burdensome.

- IBM suggests inclusion of attributable owner information on the Application Data Sheet (ADS).

- IBM supports the Office's suggestion regarding a tool for bulk processing of changes to attributable owner for patent portfolios. IBM generally supports the Office's efforts to provide a platform for voluntary disclosure of licensing information.

Additional views on the Notice and Supplemental Notice:

- IBM has grave concerns regarding the Office's proposed penalty of abandonment for failure to comply with the attributable owner disclosure requirements during patent prosecution (no penalty for post issuance failure is indicated in the proposed rules). The penalty of abandonment seems disproportionately harsh and inconsistent with the character of the requirement.

- The penalty of abandonment is also disproportionate to the harm to the public of failure to disclose ownership information during prosecution, especially since it is easy to correct such harm.

- IBM strongly encourages the Office to conduct a pilot program to determine the appropriate scope of the definition of "attributable owner" and the optimal means for reporting this information to the Office. A pilot program would allow the Office to evaluate compliance 42 and impact on an experimental basis, and 
Table 1: Submitted comments of firms to the USPTO Notice (part 4).

\begin{tabular}{|c|c|}
\hline & $\begin{array}{l}\text { avoid widespread misunderstandings or gaps } \\
\text { created by unworkable elements of the overall } \\
\text { system. }\end{array}$ \\
\hline \multicolumn{2}{|c|}{$\begin{array}{c}\text { Intellectual Ventures } \\
\text { (Other professional, scientific and technical activities) } \\
\end{array}$} \\
\hline $\begin{array}{l}\text { The Notice does not demonstrate that the proposed } \\
\text { rules are necessary for; } \\
\text { - Verifying the power of attorney. } \\
\text { - Avoiding conflicts of interest. } \\
\text { - Identifying commonly owned prior art and } \\
\text { double patenting. } \\
\text { - Post-issuance proceedings. } \\
\text { - Improving the accuracy of public information. } \\
\text { The proposed rules are overbroad and unduly } \\
\text { burdensome. } \\
\text { - The definition of attributable owner is broad and } \\
\text { unworkable. } \\
\text { - Determination of attributable ownership is } \\
\text { beyond the skills of all patent agents and most } \\
\text { patent attorneys. } \\
\text { - Mandatory disclosure of attributable ownership } \\
\text { impacts legitimate privacy and business } \\
\text { interests. } \\
\text { - The proposed rules potentially conflict with } \\
\text { other legal requirements. } \\
\text { of rules conflict with statute and other branches } \\
\text { government. The proposed rules are a } \\
\text { significant regulatory action under Executive } \\
\text { Order } 12866 \text {. There are a number of additional considerations } \\
\text { - Regulation costing more than } \$ 100 \text { million } \\
\text { require OMB approval. } \\
\text { - The UsPTO's } \$ 43.5 \text { million estimate is based on } \\
\text { - Lessoneous assumptions. } \\
\text { higher costs. } \\
\text { under Executive Order } 12866 .\end{array}$ & $\begin{array}{l}\text { - Intellectual Ventures recommends that the } \\
\text { USPTO act within its current legal authority to } \\
\text { improve the management and dissemination of } \\
\text { information that it already possesses } \\
\text { concerning titleholder, power of attorney, and } \\
\text { terminal disclaimers. Cross-linking and } \\
\text { modernizing the USPTO's existing databases is } \\
\text { badly needed. } \\
\text { - Intellectual Ventures also recommend that the } \\
\text { USPTO convene an experts group to study } \\
\text { solutions to the alleged problems identified in } \\
\text { the Notice, including working with the } \\
\text { USPTO's international partners to ensure that } \\
\text { the USPTO's efforts promote, rather than } \\
\text { impede, patent harmonization efforts through } \\
\text { the IP5, Trilateral Offices, and Tegernsee } \\
\text { Group. }\end{array}$ \\
\hline \multicolumn{2}{|c|}{$\begin{array}{c}\text { Microsoft Corporation } \\
\text { (Other software publishing) }\end{array}$} \\
\hline $\begin{array}{l}\text { - Microsoft has been a vocal supporter of greater } \\
\text { transparency in the patent system. On March 28, } \\
\text { 2013, Microsoft launched a "Patent Tracker" tool } \\
\text { that provides a list of all of the patents Microsoft } \\
\text { owns and urged other companies to follow suit, } \\
\text { as it firmly believes that greater transparency } \\
\text { will yield tangible outcomes that enhance } \\
\text { American competitiveness, create jobs and foster } \\
\text { growth in nearly every sector of the U.S. } \\
\text { economy. } \\
\text { - Microsoft therefore applauds the USPTO for3 } \\
\text { devoting attention to improving transparency by } \\
\text { examining changes to "the rules of practice to }\end{array}$ & $\begin{array}{l}\text { - With respect to the specific rule changes set out } \\
\text { in the Proposed Rules, Microsoft supports the } \\
\text { submission made by BSA|The Software } \\
\text { Alliance. }\end{array}$ \\
\hline
\end{tabular}


Table 1: Submitted comments of firms to the USPTO Notice (part 5).

facilitate the examination or patent applications and to provide greater transparency concerning the ownership of patent applications and patents." 79 Fed. Reg. at 4105 . One of the main functions of patents is to provide notice to the public of both the invention and who owns it. Disclosure of the real party in interest for a particular patent reduces the likelihood of opportunistic behavior and gamesmanship and helps to facilitate licensing and the dissemination of technology.

Novartis AG.

(Manufacture of pharmaceutical preparations)

- The proposed attributable ownership rules are far broader than necessary to achieve their intended goals, and should be substantially narrowed to avoid unduly burdening legitimate users of the patent system.

- The proposed attributable ownership disclosure rules have the potential to harm innovators and licensees, undermining many of the rules' stated goals.

- The "purpose or effect" catch-all of \$1.271(c) could harm innocent third parties.

- The rules as proposed are unnecessarily burdensome and costly, and the proposed penalty is unduly severe.

- The goal of reducing risk abusive patent litigation should be addressed separately, through a set of rules that targets the source of that problem.

- The remaining external goals an all internal goals can be achieved through the adoption of a mandatory patent assignment database.

- Based on the concerns raised, Novartis urges the Office to consider removing exclusive licensees (an "entity necessary to be joined in a lawsuit in order to have standing to enforce the patent", 1.271(a)(2)) from the attributable ownership definition. Should the Office, despite these concerns, decided to maintain the current definition, Novartis requests that it at least considers limiting the application of this definition to disclosures related to the filing of a complaint, or at most, to the sending of a demand letter, as proposed in section IA of these comments. If the Office does not agree with either of these proposals, Novartis further asks that it considers implementing these rules only prospectively, limiting the attributable ownership disclosure requirement to patent applications filed after the effective day of any final rules, and patents and application exclusively licensed after that date. This would at least eliminate the risks relating to current license agreements that lack provisions to adequately address attributable ownership disclosure requirements, and provide licensing parties with fair notice of the risks that the rules pose to the confidentiality of their agreements.

- Novartis respectfully submits that no attributable owner definition should contain a vague and uncertain catch-all category that includes subjective standards like "purpose or effect' such as proposed in 37 CFR 1271 (c). If the Office insists that such a category is necessary - for example, to achieve the goal of reducing the risk of abusive patent litigation then it should be narrowly tailored to those 
Table 1: Submitted comments of firms to the USPTO Notice (part 6).

arrangements that are intended to mask a party from being identified or named in a legal action. As discussed in Section IA of these comments, it should also be narrowly applied to only those circumstances and entities where such litigation abuses are probable.

- For the reasons previously discussed, even where a change has occurred, Novartis urges the Office to reconsider whether so many reporting events are truly necessary, where, as explained and proposed, narrower rules can achieve the same goals while reducing the burdens on patentees and applicants. Whether or not the Office maintains these reporting events for situations where the attributable ownership has changed, however, Novartis does not see justification for requiring reporting when all attributable owners have remained the same.

- While the proposed rules make some effort to ameliorate the severity of the penalties by extending the reporting deadline for one event and allowing for corrections of certain error or omissions that occur for others, both of these provisions are, in Novartis' view problematic. For the deadline extension, if the rules are to include penalties as severe as abandonment, Novartis believes that the extension should be available for all reporting events, coupled perhaps by payment of a late fee, ideally without a requirement to file a petition, which seems unnecessary in most circumstances. Regarding the proposed correction procedure for other events, this procedure seems to apply only to cases where a "good faith effort" was made to comply with the rule, and it is not clear what this standard entails. If standard correction is required at all, Novartis proposes that the standard at least be consistent with that of 35 U.S.C 255, requiring only that the error be one made in good faith, rather than requiring a showing that "good faith efforts" were made to Ocean Tomo LLC comply with the rules.

(Other activities auxiliary to financial services, except insurance and pension funding)

- Ocean Tomo supports USPTO Proposed • n/a

Changes to Require Identification of Attributable

Owner. It supports such disclosure not only at the time of initial filing but also with any change of assignment. It concurs with the proposition that such disclosure will further improve market efficiency for patent rights.

- Intellectual property is taking up an increasingly large footprint on corporate balance sheets and iq 45 driving significant value for companies 
Table 1: Submitted comments of firms to the USPTO Notice (part 7).

\begin{tabular}{|c|c|}
\hline \multicolumn{2}{|l|}{$\begin{array}{l}\text { investing in obtaining IP through R\&D. Changes } \\
\text { such as those described here will produce } \\
\text { dividends to owners of IP through increased } \\
\text { awareness of such assets as well as reduce } \\
\text { transaction costs. }\end{array}$} \\
\hline \multicolumn{2}{|c|}{$\begin{array}{c}\text { Oracle Corp } \\
\text { (Other software publishing) } \\
\end{array}$} \\
\hline $\begin{array}{l}\text { - Oracle supports the United States Patent and } \\
\text { Trademark Office's efforts to adopt procedures } \\
\text { designed to increase patent ownership } \\
\text { transparency. It is in favor of enhanced } \\
\text { ownership disclosure rules that will apply to } \\
\text { both patent applications and issued patents, and } \\
\text { commends the PTO's Proposed Rule as a } \\
\text { significant step in the right direction. Oracle } \\
\text { agrees with written comments submitted by the } \\
\text { Coalition for Patent Fairness (of which Oracle is } \\
\text { a member), and submits this brief additional } \\
\text { comment to underscore its view that the } \\
\text { disclosure requirements for issued patents } \\
\text { outlined in the Proposed Rule should go further } \\
\text { by requiring patent owners to file updated } \\
\text { attributable ownership information at more } \\
\text { frequent intervals. }\end{array}$ & $\begin{array}{l}\text { - In its current form, the Proposed Rule requires } \\
\text { filing updated post-issuance patent ownership } \\
\text { information only when patent annuities are } \\
\text { paid and when a patent has already become } \\
\text { involved in a post-grant proceeding. The very } \\
\text { long intervals between required filings of } \\
\text { updated ownership information create } \\
\text { significant gaps in the disclosure process that } \\
\text { could be exploited by patent owners. } \\
\text { Attributable ownership information could } \\
\text { change, potentially many times, during the } \\
\text { multi-year periods between required updates. } \\
\text { For instance, under the Proposed Rule, a patent } \\
\text { owner could wait until the third maintenance } \\
\text { fee has been paid, and then transfer ownership } \\
\text { of the patent to a shell company controlled by } \\
\text { a different entity. The PTOand the public could } \\
\text { be denied accurate attributable ownership } \\
\text { information for the patent for years, unless and } \\
\text { until the patent has become involved in a post- } \\
\text { grant proceeding. Such long disclosure gaps } \\
\text { undermine the very important transparency } \\
\text { objectives that the Proposed Rule seeks to } \\
\text { advance. In order to avoid this potential for } \\
\text { abuse, in addition to obligations to fill updated } \\
\text { ownership information when patent annuities } \\
\text { are paid and when a patent becomes involved } \\
\text { in a post-issuance proceeding, Oracle } \\
\text { respectfully suggests modification of the } \\
\text { Proposed Rule to require reporting any change } \\
\text { of attributable ownership within three months } \\
\text { of such a change during the enforceable } \\
\text { lifetime of an issued patent. This modification } \\
\text { would bring the post-issuance reporting } \\
\text { obligation in line with the reporting obligation } \\
\text { that the Proposed Rule would apply during the } \\
\text { pendency of a patent application and would } \\
\text { avoid the long disclosure gaps discussed } \\
\text { above. }\end{array}$ \\
\hline
\end{tabular}

Patentbooks Inc.

(Other activities auxiliary to financial services, except insurance and pension funding)

- Patentbooks Inc. (PBI) does not believe that the $\bullet \mathrm{n} / \mathrm{a}$

proposed rule, with the additional costs and

drains on USPTO resources that administering

the rule requires, is necessary or justified.

- PBI supports a market-based system that will

allow large-scale patent licensing for specifit6

products on a utility basis for specific products 
Table 1: Submitted comments of firms to the USPTO Notice (part 8).

(so that licensing patents will become as easy as

obtaining water or electricity). Such a system will promote innovation by making available to intellectual property users multiple patents offering competing solutions, so that users may choose among these patents in developing their products or services.

- The system PBI advocates also will provide for frequent regular payments directly into the accounts of patent owners from the pool of revenues provided by patent users. For this system to function effectively, it is important that patent owners provide the system administrator with their identity and the information necessary to meet financial and tax requirements (and that such information be updated periodically) so as to assure that the payments attributable to listed patents can be directed efficiently into the appropriate bank accounts.

- Because the patent owners in this system will have a financial incentive to provide the types of patent ownership information the rule is seeking, PBI believes that its market-based solution will provide such information on a commercially driven basis at no direct cost to the government. Moreover, PBI is willing to share the ownership information that it gathers with government agencies needing such information (e.g., the USPTO and US Customs and Border Protection) for appropriate reasons. For this reason, PBI does not believe that the proposed rule, with the additional costs and drains on USPTO resources that administering the rule requires, is necessary or justified.

Pfizer Inc.

(Manufacture of pharmaceutical preparations)

- The disclosure of "enforcement entities" and Pfizer believes that the following concepts should "hidden beneficial owners" is not necessary, be eliminated from the PTO's proposed rules: effective or feasible and is premature, overly - Any requirement to name "enforcement intrusive and burdensome.

- Continuous updating of ownership information during prosecution and PTAB proceedings, particularly where there is no change in ultimate parent entity, is neither necessary nor feasible and would be unduly burdensome.

entities" or "hidden beneficial owners".

- Any requirement to continuously update ownership during prosecution or other proceedings where no change in ultimate parent entity of legal title holder occurs.

- Automatic abandonment for failure to identify ownership information at the time of filing or failure to update such information at payment of the issue fee is unduly punitive. At the filing stage, inventors are already required to be listed and the initial POA must be signed by the applicant, so punishing the applicant for not providing the same information in another form is inappropriate. And the fact that a paten 47 would be subject to an inequitable conduct claim 
Table 1: Submitted comments of firms to the USPTO Notice (part 9).

\begin{abstract}
if a party fails to provide or update other ownership information with intent to deceive and causes real harm to the PTO proceedings or a third party would be a sufficient deterrent to abusive behavior.
\end{abstract}

- The PTO significantly underestimates the number and type of affected parties and the level of additional effort and cost needed to comply with its proposed rules.

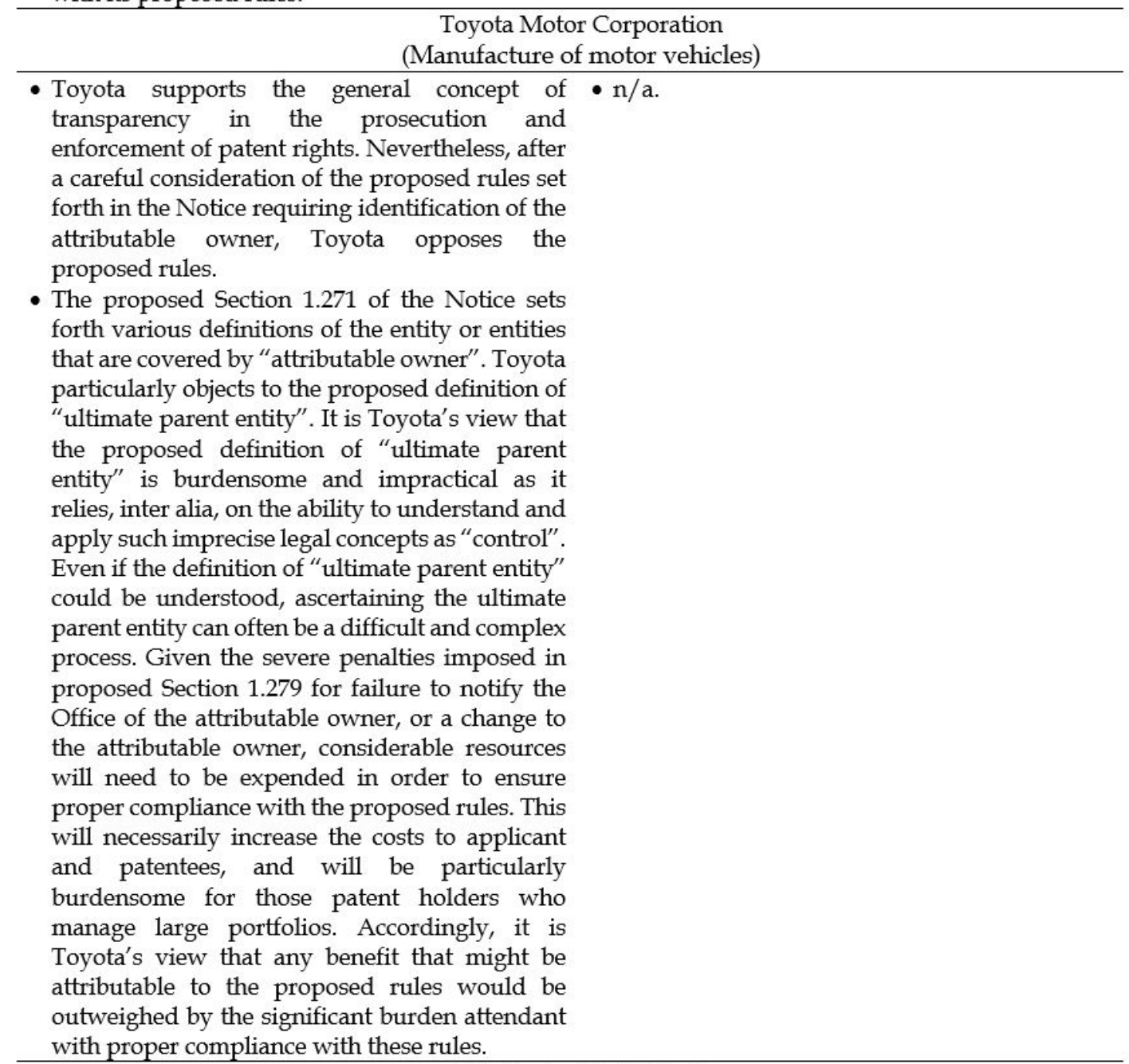
with proper compliance with these rules.

(Other business support service activities)

- Wayfinder Digital supports USPTO's effort to - Adopt the legal entity identifier.
increase information transparency with respect - Require update of attributable ownership
to the attributable ownership of patents and when there is a material change at any of the
patent applications. It believes that the patent attributable owners of patents.
compact through which inventors and - Do not exclude government entities from
titleholders are granted exclusive use of the reporting when they own or have interest in a
patented invention in exchange for disclosure of patent.
the invention includes the disclosure of complete 48 Adopt the us navy's patent information
and accurate information on who owns a patent disclosure approach.


Table 1: Submitted comments of firms to the USPTO Notice (part 10).

$\begin{aligned} & \text { or patent application and how to contact the } \\ & \text { attributable owners. This reporting does not } \\ & \text { introduce a burden on the patent owner and can } \\ & \text { landscape for innovators. } \\ & \text { be accomplished electronically at a minimal cost. } \\ & \text { The availability of this information is an essential } \\ & \text { geographic data. }\end{aligned}$ Enable the public to identify bad data for
correction.
element of a functioning patent system in today's
global innovation economy.
- Affirmatively identify abandoned patents.
address "broken windows", the information
asymmetry in the US patent system. The lack of
information transparency is the broken window
within the US patent system frustrating
innovators, entrepreneurs and business owners.
It facilitates aggressive patent monetization
behavior, clandestine patent privateering pacts,
the inability of firms to defend themselves
against frivolous patent lawsuits and submarine
infringement claims that coincide with the
announcement of a new product or a new
significant round of venture capital for science
and technology-based firms. In the age of
ubiquitous information disclosure, patent
information inscrutable.
Implementation of attributable ownership rules
is an opportunity to improve information
transparency in the US patent system across the
board.

after their occurrence 211 The USPTO Notice imposes much stricter obligations to applicants during the patent application process than to owners post-grant. Whereas patent applicants are required to disclose the identity of the attributable owner(s) at the date of filing and notify the office of changes of attributable ownership during the patent application phase, once the patent is granted, the patent holders are only required to submit information about the identity of the attributable owner(s) upon payment of maintenance fees or during post-grant proceedings in front of the office. In jurisdictions where the payment of maintenance fees is due after short time intervals this requirement might be sufficient to provide a constant flow of accurate ownership information to the public. However, in the US patent system, where the payment of maintenance fees is due after three, seven and eleven years the long time-intervals between these events only allow for an occasional availability of ownership information. Given that the final maintenance fee for a US patent is due after eleven years, this entails that in the worst-case scenario changes of ownership that occur directly after the payment of this fee may not be observable for a period of up to nine years.

211 See e.g. the comments submitted by Hewlett-Packard Company and Oracle Corp. in Table 3.1. 
We also propose that ownership information should only be notified to a patent office when a change of ownership has effectively occurred. The USPTO Notice specifies that owners should give notice of the identity of the attributable owner(s) at specific moments during the patent life-cycle regardless of whether a change of attributable owner(s) has taken place. However, we support the arguments submitted by multiple stakeholders of the patent system during public hearings which indicate that this requirement may be unduly burdensome, given that the attributable ownership does not change at all during the lifetime of the far majority of patents 212 We believe that requiring the submission of attributable owner information only when an ownership change has occurred minimizes the burdens for submitting this information whilst maximizing its accuracy.

\subsection{Corrective actions for non-compliance with requirements concerning the disclosure of ownership}

We propose that any failure to comply with the disclosure requirement concerning the identity of the title holder(s) and her/their ultimate parent entity following any change of ownership should lead to punitive action in the form of abandonment of the patent (application) even though most stakeholders find this an excessive penalty ${ }^{213}$ The USPTO Notice foresees such a penalty only in case of failure to meet this requirement during the pendency of a patent application and at the moment that a notice of allowance has been sent to the applicant and does not indicate penalties for failure to meet requirements post-issuance. Given that the primary motivation for initiating future initiatives aimed at improving the transparency of patent ownership is based on the conviction that a voluntary recordation system is insufficient to achieve a satisfactory level of such transparency, we believe that an effective enforcement of requirements must incorporate penalties for non-compliance that are administered consistently. We believe that the prospect of facing an abandonment of a patent (application) will incentivize parties to record ownership changes to a far greater extent than recordation on a voluntary basis. Given the severity of the penalty of abandonment, we suggest a sufficient time window for correcting errors made in good faith.

\subsection{Platforms for recording and disclosing submitted ownership informa- tion}

We propose that the potential burden and costs associated with the submission and retrieval of ownership information should be minimized by providing an on-line, easy to access and freeof-charge platform for submitting and retrieving such information. We believe that allowing

\footnotetext{
212 See e.g. the comments submitted by Novartis AG and Pfizer Inc. in Table 3.1.

213 See e.g. the comments submitted by the Cook Group, IBM Corporation, Pfizer Inc. and GlaxoSmithKline in Table 3.1 .
} 
parties to submit ownership information free-of charge on such a platform will greatly lower the burdens and costs that parties are currently facing when submitting ownership information to most patent offices. At present, the USPTO is the only patent office that offers the possibility to record patent assignments online without charges, although the retrieval of recorded assignment documents is only made possible upon written request against a fee of 25 dollars. We contend that making ownership information readily available to the public, free-of-charge through an on-line platform immediately after processing the submitted information (with the exception of ownership changes that involve patent applications that have not yet been published and are subject to secrecy requirements) is equally important as allowing parties to submit such information 214 We believe that such an approach will allow a patent office to draw upon the public for the identification and communication of incorrect ownership information to the office, which will significantly improve the accuracy of such information 215

\section{Concluding Remarks}

In this paper we aimed to highlight issues concerning the disclosure of patent ownership information which, rather than facilitating organizations' patent monetization activities, might instead act as a barrier to these activities. We have argued that the market for patent monetization relies to a great extent on the effectiveness of the patent system's notice function. The ability to know both the boundaries that define a claimed invention as well as the identity of the parties that hold rights to this invention is a primary requirement for the initiation of technology transactions. In particular, based on a comparative analysis of the patent provisions of six of the most active patent offices worldwide - the EPO, the USPTO, the JPO, the INPI, the DPMA and the UK IPO - we addressed recently expressed concerns that current provisions provide only limited opportunities for tracking changes of ownership. We find support for the legitimacy of these concerns, our analysis reveals that although all six patent offices under study impose strict requirements concerning the identification of the initial applicant(s) of a patent, they do not impose and/or enforce such strict requirements with respect to the disclosure of the identity of the new owner(s) following a change of ownership. Furthermore, there is generally no legal basis to impose punitive action following failure to report ownership changes. As a result, the disclosure of the identity of the new owner(s) following ownership changes is largely left to the discretion of the new owner(s) and takes place on a voluntary basis. Therefore, the likelihood of identifying the actual owner(s) of a patent may be significantly reduced following changes in the ownership of the patent.

Despite the potentially negative implications of a limited transparency of patent ownership for technology markets, we are only aware of one initiative that aims specifically to address the

\footnotetext{
214 See the comments submitted by IBM Corporation in Table 3.1.

215 See the comments submitted by Patentbooks Inc. in Table 3.1.
} 
flaws of current patent provisions, the USPTO's Notice on "Changes to Require Identification of Attributable Owner". Although the USPTO has ultimately decided not to advance the proposed provisions, we have drawn upon these provisions as a basis for proposing recommendations for future initiatives. Based on the conviction that the disclosure of information on the identity of parties holding rights to a patent is part of the quid pro quo of granting exclusive rights to a claimed invention to these parties, we propose four minimal requirements that future initiatives by patent offices should impose to warrant a more adequate, accurate and timely disclosure of patent ownership information. Firstly, we suggest that the requirement to disclose information about the identity of the applicant/owner of a patent (application) should be confined to the name(s) and registered address of the exclusive or joint titleholder(s) and its/their ultimate parent entity. Secondly, we suggest that future initiatives should impose requirements to record changes of ownership regardless of when they occur during the patent lifecycle, within a reasonable time window after their occurrence. Thirdly, we suggest that any failure to comply with the disclosure requirement concerning the identity of the title holder(s) and its/their ultimate parent entity following any change of ownership should lead to punitive action in the form of abandonment of the patent (application). Lastly, we suggest that the potential burden and costs associated with the submission and retrieval of ownership information should be minimized by providing for an on-line, easy to access and free-of-charge platform for submitting and retrieving such information.

We believe that our recommendations strike a fair balance between ensuring a consistent flow of information that allows technology markets to function efficiently and the potential of imposing unduly burdensome requirements that may negatively impact the legitimate confidentiality of business interests. We hope that this paper will inspire academics and policy makers to actively engage in combined efforts to find solutions that improve the transparency of patent ownership. 
MANAGEMENT, STRATEGY AND INNOVATION (MSI) Naamsestraat 69 bus 3535

3000 LEUVEN, Belgium

$$
\text { tel. + } 3216326700
$$

msi@econ.kuleuven.be

https://feb.kuleuven.be/research/MSI/ 